\title{
A SIMYLLA DO PÉRIPLO DO MAR ERITREU: ESCAVAÇÃO ARQUEOLÓGICA DO ANTIGO SÍTIO PORTUÁRIO DE CHAUL NA COSTA OESTE DE MAHĀRĀṢṬRA - ÍNDIA
}

\author{
Vishwas D. Gogte* \\ Cibele E. V. Aldrovandi**
}

\begin{abstract}
GOGTE, V.D.; ALDROVANDI, C.E.V.A Simylla do Périplo do Mar Eritreu: escavação arqueológica do antigo sítio portuário de Chaul na costa oeste de Mahārāștra - Índia. Rev. do Museu de Arqueologia e Etnologia, São Paulo, 15-16: 247-269, 2005-2006.
\end{abstract}

RESUMO: O artigo apresenta os resultados da pesquisa arqueológica realizada pela equipe do Deccan College Post-Graduate and Research Institute no sítio portuário de Chaul, mencionado nas fontes textuais da antiguidade como um dos maiores centros comerciais da costa oeste da Índia. As evidências arqueológicas recuperadas nas explorações e escavações comprovaram sua existência desde os períodos Maurya e Sātavāhana. Fragmentos de ânforas romanas também foram encontrados. Três conjuntos de grutas budistas associados ao período Sātavāhana foram explorados junto ao sítio de Chaul. A ocupação continuada de Chaul foi atestada por mais de 2000 anos, até o século XVII, época em que o porto perdeu sua importância econômica para Mumbai.

UNITERMOS: Índia Antiga - Arqueologia - Economia - Sātavāhana - Roma Budismo.

\section{Contextualização histórica da região de Chaul - as fontes textuais}

O emporium indiano de Simylla foi localizado por Marinus a oeste do Cabo Comorim e também do rio Indo, no entanto, aqueles que ali navegaram e conhecem-no há tempos dizem estar ao sul do rio e que este lugar é chamado localmente Timoula.

(*) Deccan College Post-Graduate and Research Institute. Pune, Mahārāșțra, Índia.

$\left.{ }^{(* *}\right)$ Doutora em arqueologia pelo Museu de Arqueologia e Etnologia da Universidade de São Paulo. aldrovan@yahoo.com
De tais pessoas nós viemos a saber outras cousas sobre a Índia, especialmente sobre suas províncias e as terras altas.

Ptolomeu [Geografia I.17]

\section{I.1. A Chaul antiga}

As fontes literárias mencionam, desde a antiguidade, o sítio portuário de Chaul sob nomes distintos como Chemula, Semylla, Simylla, Symulla, Timulla, Timoula, Chimolo, Sibor, Saimur, Jaimur e Ceul.

A antiga Chaul pode ter sido chamada Campāvati ou Revatikṣetra no poema épico Mahābhārata e, segundo alguns autores, sua existência remontaria à época em que o lendário 
Kṛṣna teria reinado no Gujarat ${ }^{1}$. As fontes sobre o período Maurya e Sātavāhana na região do Konkan são escassas e não parece haver qualquer documentação histórica que mencione a cidade de Chaul. No entanto, a existência do antigo porto está atestada em inscrições, nas grutas budistas de Kānheri, próximas a Mumbai e datadas de c. 130 d.C., nas quais Chemula é mencionada como local de residência de dois irmãos que fizeram doações ao monastério. ${ }^{2}$ A cidade aparece novamente como Chemula numa inscrição do século $\mathrm{V}$ d.C. ${ }^{3}$

A cidade de Chaul foi, possivelmente, um dos mais importantes centros comerciais da antiguidade durante o período Romano e aparece citada nas fontes históricas ocidentais. Durante o período imperial romano o crescimento do porto de Chaul esteve associado ao florescimento do comércio de algodão, registrado no ano de 69 d.C., durante o governo de Vespasiano. ${ }^{4}$ No século II d.C., Ptolomeu [Geografia I.17] mencionou a antiga Chaul como Simylla ou Timoula, entre o rio Binda e a enseada Bassein ou Balipatna, isto é, Palepattan ou Mahad. ${ }^{5} \mathrm{O}$

(1) Estudos atribuem esse período a c. 1200 a.C., no entanto, tais datas são controversas. No Mahābhārata, a cidade teria possuído 1.600 .000 edifícios, 360 templos e 360 lagos e era dividida em dezesseis distritos ou pakhadya; três deles teriam formado a Chaul portuguesa - Dod, Dakhavada e Murad (Da Cunha 1876:106-9).

(2) Nagaraju (1981:198;333-4) citou as duas inscrições (n 9 e 11): a primeira encontrada acima da cisterna dupla na gruta 6 , que foi doada por um mercador de Sopārā e por Sulasadata de Chemula [Chemulakasa heranikasa Rohinimitasa putasa Sulasadatasa poḍi deyadhamma]; a segunda, no caminho acima da escavação no.7 [Chemulikasa heranikasa (Sethini)mitasa putasa Dhamanakasa patho deyadhama]. O Bombay Gazetteer (XVI:172) acrescenta que Sulasadatta era um ourives de Chemula. Ver também as inscrições de Kānheri 12 e 20, em Burguess (1883).

(3) A execução da gruta foi financiada por um mercador descrito como famoso entre os ricos da grande cidade de Chemula, aquele cuja fama se difundiu pelos três mares. Ver Bombay Gazetteer (XVI:173,189).

(4) Ver Warmington (1928:108-12,289-90). Para referências sobre a Índia durante Vespasiano, ver Plínio [História Natural]; para demais obras antigas ver MacCrindle (1901; 1060); Warmington (1934); Filliozat (1949); Raschke (1979); Casson (1980); Karttunen (1989); e Cimino (1994).

(5) Ver Ptolomeu (1883); Sastri (1927:42-3); e o estudo mais recente em Lennart Berggren \& Jones $(2001: 79,128)$. Warmington (1928:113) observou que o Konkan foi descrito por Ptolomeu como o distrito dos piratas; a região teria permanecido sob ataques até o século XIX, época em que os ingleses eliminaram os corsários. porto de Chaul é citado no Périplo do Mar Eritreu como Simylla e é descrito como o primeiro mercado ao sul de Kalliena ${ }^{6}$ (Fig. 1). O mercador grego do século VI, Kosmas Indikopleustes, mencionou a região de Sibor em seu Topographia Christiana (Bibliotheca Cleri Universe, I, 525:50), em 525 d.C., como um grande centro comercial entre os portos de Kalyāṇ (Kalliena) e Malabār (Kerala). Um século mais tarde, por volta de 642 d.C., Chaul pode ter sido visitada pelo peregrino budista chinês Hiuen Tsang, que a descreveu como Cimolo (Foe Koue Ki [391], ver Julien 1858: I.193).

\section{I.2. A Chaul intermediária}

Durante os séculos X a XIV d.C., a cidade portuária de Chaul esteve sob o poder dos Śilahārā, como foi também chamada a dinastia indiana dos Rāștrakūṭa, que governou o Konkan entre 820 e 1260 d.C. Nos relatos dos viajantes árabes dos séculos X ao XII, o porto de Chaul é mencionado sob o nome de Saimur e Jaimur. Durante a visita de Masudi, em 915, Saimur era governada por um príncipe Śilahārā, chamado Djandja, ou Jhanjha. Nessa época a cidade possuía uma população muçulmana próspera de aproximadamente dez mil habitantes, entre os quais alguns mercadores muito respeitados que, com a permissão real, construíram várias mesquitas na região. A língua da população foi descrita como o lari, ou seja, o gujarate. $^{7}$

(6) Ver MacCrindle (1905:129); Schoff (1912 e 1917); Palmer (1947); Pirenne (1961); Macdowall (1964); Huntingford (1980); e Casson (1989). O documento anônimo, que possui datação controversa, menciona uma série de portos na região do Konkan, costa oeste da Índia: Barygaza, Souppara, Kalliena, Simylla, Mandagora, Palaepatmai, Meliziegara e Byzantion; nele estão descritas as rotas, períodos favoráveis para viagens, os bens comercializados nos portos e os monopólios dos governos locais. Warmington (1928:289) considerou o documento anterior a Ptolomeu. A pesquisa de Casson (1989) concluiu que o documento era do século I d.C., mas outros autores, como Huntingford (1980), estabelecem datas mais tardias, como o ano de 247d.C. Para uma discussão das diversas datas propostas, ver Majumdar \& Pusalkar (1953); e Dehejia (1972:22-5).

(7) Masudi (Prairies d'Or, II:85-7). O gujarate pode ter sido a língua comercial de Chaul, como ainda o é em Mumbai. Para a estatística populacional, Bombay Gazetter (XIII:422). Outros viajantes árabes como Muhalhil (941 


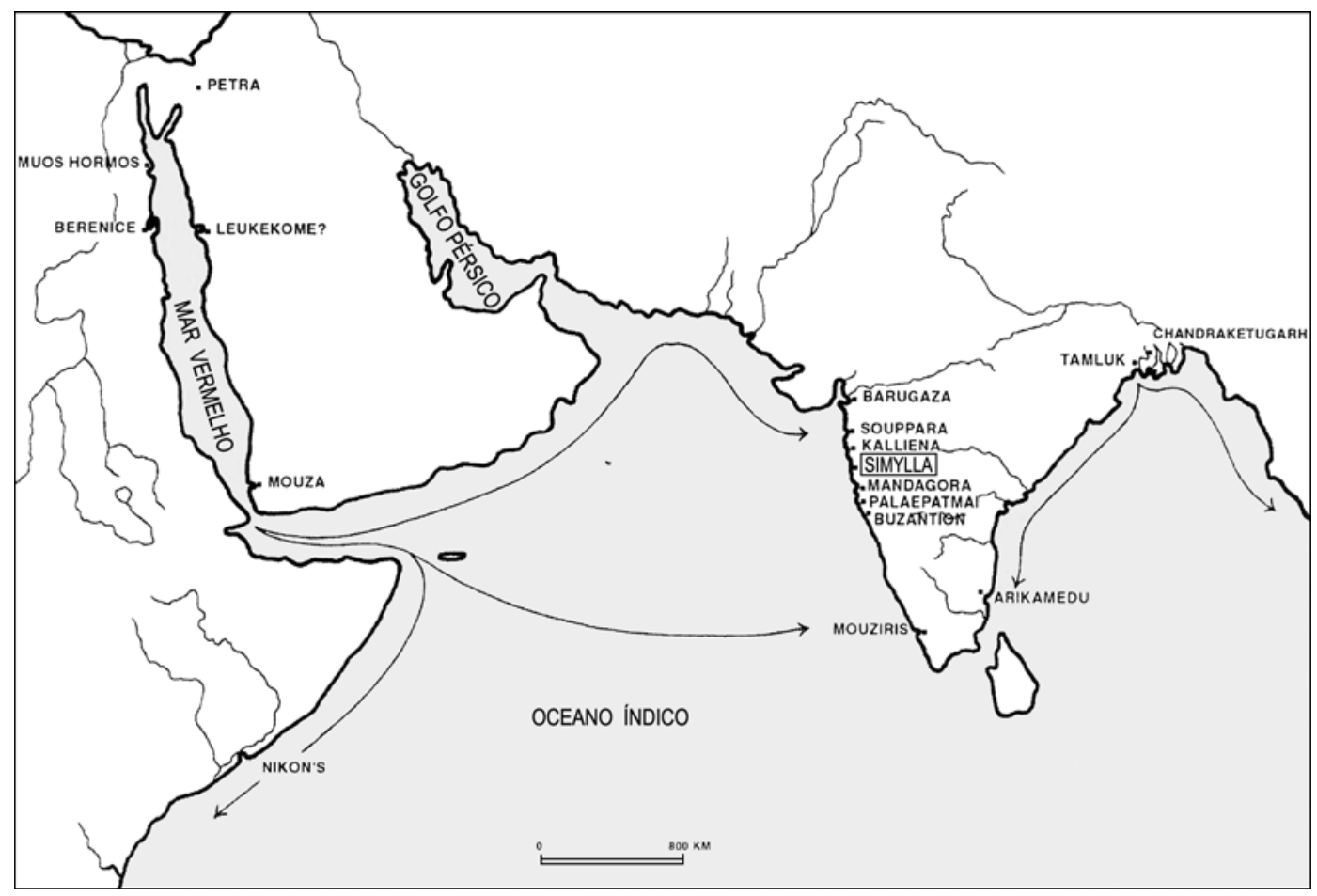

Fig. 1 - Principais portos comerciais mencionados no Périplo do Mar Eritreu (Gogte 2004).

Numa placa de cobre do século XI d.C., atribuída ao décimo quarto rei Śilahārā, Anantdev (1094 d.C.), Chaul aparece como Cemuli e é mencionada como um porto equivalente a Sūrpāraka (Sopārā) e Șristhānāka (Ṭhānāā) (ver Maharashtra State Gazetteers 1964:717-9; e Indian Antiquary IX:38). No século XIII, Chaul pode ter sido governada por um membro da família Devgirī da dinastia Yādava que teria atacado o governante de Māhim (Mumbai). No século XIV, esse centro de poder Yādava no Konkan foi subjugado pelo general muçulmano Malik Kafur, designado por Ala-ud-din Khilji (1297-1351). A descoberta de uma inscrição kanada, junto ao templo Rameśvar em Chaul, indica que o poderio muçulmano foi

d.C.), Ibn Haukal (976 d.C.), Al Biruni (1030 d.C.) e Al Idrisi (1130 d.C.) também forneceram importantes informações sobre Chaul. No ano de 942 d.C. ali viviam, além dos hindus, muçulmanos, cristãos, judeus e parsis; haviam templos hindus, assim como mesquitas, igrejas, sinagogas e os templos de fogo dos zoroastristas. Ver Maharashtra State Gazetteers (1974:719). derrotado, em seguida, pelo Vice-rei de Goa, e passou à autoridade do rei hindu Vijayanagar ou Anegundi (1336-1587). No entanto, no final do século XIV, a região se encontrava sob controle dos hindus Bahamani.

\section{I.3. A Chaul tardia}

A região do Konkan foi governada, no período tardio, pelos hindus Bahamani (1397-1422) e, em seguida, pela dinastia brâmane Ahmadnagar (14901595 d.C.). Nos séculos que se seguiram, Chaul foi visitada e comentada por muitos viajantes europeus, como o russo Nikitin (1470) que a chamou Chivil, o português Barbosa (1514) menciona-a como Cheul, e o inglês Fitch (1584), que utilizou seu nome atual. ${ }^{8}$

As fontes escritas narram a chegada dos primeiros portugueses ao porto de Chaul por volta

(8) Para uma listagem de viajantes e dos nomes atribuídos a Chaul, ver Maharashtra State Gazetteer (1964:716). 
do ano 1505. As naus chefiadas pelo comandante Dom Lourenço de Almeida, filho do então Vice-rei, atacaram e venceram os rivais muçulmanos e ofereceram proteção ao rei hindu da dinastia dos Ahmadnagar, em troca de ouro. Acordos foram firmados entre o rei indiano e os portugueses e 0 comércio portuário cresceu. Por volta de 1514, a cidade de Chaul era o único grande centro comercial entre Surat e Goa, especialmente nos meses de inverno (dezembro a março), nos quais um grande mercado era organizado nas adjacências dessa área. O comércio marítimo desenvolveu-se tanto entre Chaul, o Golfo Pérsico e Arábia, quanto com a região costeira indiana, especialmente Goa, 0 Malabār ao sul e o Gujarate ao norte. ${ }^{9}$ Após um ataque das tropas de Bijāpūr, Chaul foi queimada em 1521 e o rei hindu pediu aos portugueses que construíssem um forte na Chaul baixa. Apesar das investidas inimigas subseqüentes, a fortaleza (ver Da Cunha 1876:39-42) foi concluída em 1524. Poucos anos depois, uma armada do Gujarate atacou Chaul e venceu a esquadra portuguesa. $\mathrm{O}$ rei brâmane dos Ahmadnagar, Burhān Nizām, foi subjugado pelo soberano do Gujarate, Bahādur Shah, forçado a reconhecer sua supremacia e a tornar-se um aliado. Após a morte do rei do Gujarate, em 1535, as relações amistosas entre os Ahmadnagar e portugueses foram restabelecidas, e Chaul voltou a ser o próspero empório da região.

Nas décadas seguintes, períodos de paz foram entremeados por ofensivas dos próprios reis Ahmadnagar, que não desejavam ver o poderio português dominar a região. Durante 1577, sabe-se que os portugueses ampliaram suas defesas e fortificações. Nesse período, Chaul era visitada por navios de Cambay, Sind, Bengala, Ormuz, Maskar e do Mar Vermelho (ver Maharashtra State Gazetteer 1964:722-5, 30).

As descrições de Chaul, durante todo o século XVI, revelam uma região extremamente próspera.

Em 1592, Burhān Nizām II, ordenou a construção do forte de Korlai, na margem esquerda do rio Kuṇạalīkā, e iniciou ofensivas contra o forte português do outro lado do rio Kuṇ̣alīiā. No

(9) Ver Da Cunha (1876:23-30, 35-7). Navios mercantes levavam para a Europa, através de Diu e Meca, grãos como trigo, arroz e gergelim, vegetais, musselina e produtos de algodão; e traziam de Portugal cobre, mercúrio e cinábrio. entanto, os portugueses conseguiram manter o controle da região. Em 1600, a cidade alta de Chaul passou para o controle do imperador mugal Akbar e foi chamada Mamale Mortezabad. Nesse período as relações entre muçulmanos e portugueses são relatadas como amistosas (ver Da Cunha 1876:42). Durante o século XVII, as conseqüências da transferência do poder naval português para os holandeses também afetaram o porto de Chaul. No entanto, alianças firmadas em 1617, entre os muçulmanos e portugueses, conseguiram manter holandeses e ingleses afastados da região, bem como os piratas do Malabār (ver Pietro Della Valle, Viaggi III, 1625:409). Em 1648, o rei marāthā Śivāji subjugou o Konkan e, por volta de 1672, seu exército havia reduzido a Chaul muçulmana a ruínas.

O declínio de Chaul deu-se por volta da metade do século XVII, decorrente, por um lado, da perda do monopólio marítimo português, suplantado pelo holandês, e, por outro, à implantação do comércio britânico em Bombaim (Mumbai), em 1666. A prosperidade e o comércio da Chaul portuguesa perderam força pois, nessa época, muitas fábricas de seda foram transferidas para a capital de Mahārāṣtra.

Em 1681, a Chaul marāthā foi pilhada pelo Sidi e o rei Sambhāji, furioso com os portugueses que não procuraram impedir o ataque, decidiu promover uma retaliação contra a Chaul portuguesa. Incapaz de vencer, ele mandou que fosse construído o forte de Rājkoț, e as ofensivas continuaram. Em 1739, a cidade-fortaleza de Bassein ${ }^{10}$ caiu sob o domínio marāthā e os portugueses também não foram capazes de manter o poderio em Chaul. Os portugueses ofereceram Chaul e Korlai aos ingleses, que os haviam auxiliado durante a tomada de Bassein. Durante as negociações de paz, em 1740, Chaul foi cedida aos marāthā que, em troca, deixaram a região de Goa para os portugueses. A partir de então, Chaul nunca mais recuperou sua importância anterior. Em 1778 uma comitiva francesa ancorou em Chaul e seguiu até Poona (atual Pune, antiga Ter ou Tagara), a partir das negociações firmadas, os marāth $\bar{a}$ transferiram o controle do porto para os franceses, aliança que parece ter causado grande constrangimento em Mumbai.

(10) Para detalhes sobre as cidades-fortaleza portuguesas na Índia, como Bassein e Damão, ver Teixeira (1996:15-26). 


\section{A pesquisa arqueológica no sítio portuário de Chaul}

Agora entramos num estágio da história de Chaul que, por falta de um desígnio melhor, pode ser denominado decrepitude.

Após passar, por assim dizer, a flor de sua juventude a se firmar nas margens de Revadanda, circundada por uma hoste de inimigos traiçoeiros; e o vigor da meia idade a resistir às reiteradas incursões $e$ sítios de seus vizinhos, a nobre cidade de Chaul cai, então, gradualmente num estado de senilidade que prediz sua dissolução próxima...

Da Cunha (1876:62)

A presente pesquisa vem sendo desenvolvida dentro do Programa de Exploração e Escavação dos Antigos Portos e Assentamentos da Costa Oeste da Índia pela equipe do Deccan College Post-Graduate and Research Institute, ${ }^{11}$ sob direção do professor V. D. Gogte. O levantamento inicial para localização de sítios arqueológicos teve início em 1998 e foi dificultado pela densa vegetação presente na região costeira e pelas fortes chuvas anuais durante o período das monções que prejudicam a investigação e exploração de depósitos habitacionais in situ. Além disso, a região esteve sujeita a mudanças geomorfológicas recentes, cujas investigações revelaram, entre outras coisas, uma elevação do nível do mar entre 4 e 5 m nos últimos 2300 anos. Apesar disso, o levantamento sistemático da região da costa oeste conseguiu evidenciar sítios arqueológicos em Chaul (Simylla), Palshet (Palaepatmai), Bagmandala e Mandad (ambas citadas como a Mandagora do Périplo), assim como Tena e

(11) O estágio de pesquisa desenvolvido no Deccan College Post-Graduate and Research Institute sob orientação do Prof. Vishwas D. Gogte, Diretor Adjunto desta instituição e arqueólogo-químico, incluiu a participação na etapa de campo de 2005. A Instituição foi fundada por ingleses, em meados do século XIX, e possui pós-graduações nas áreas de Arqueologia e Linguística. O Departamento de Arqueologia, o mais antigo instituto arqueológico da Índia, é referência internacional no desenvolvimento de pesquisas arqueológicas em toda a Ásia. O estágio foi financiado integralmente pela Fapesp.
Sanjan (Gogte 2003 e 2004; sobre Sanjan ver Gupta et al 2004).

$\mathrm{O}$ antigo porto comercial de Chaul ( $\mathrm{N}$ 18 $8^{\circ} 33^{\prime}, E 72^{\circ} 56^{\prime}$ ) pertence à faixa litorânea da costa oeste indiana, a região do Konkan. O sítio arqueológico também é conhecido atualmente como Ceul ou Revdandāa e está situado no estado de Mahārāsțra, distrito de Kolaba, a cerca de 56 $\mathrm{km}$ ao sul de Mumbai e $20 \mathrm{~km}$ a sudeste de Alibāg. A região está localizada na margem direita (norte) da foz do rio Kuṇụalīkā, na enseada Rohā. A área se encontra junto ao oceano Índico (oeste) e ao rio Kuṇ̣̂alīkā (sul e sudeste) e possui uma extensão de aproximadamente 5 km (nordeste) após a qual encontra uma cadeia de montanhas rochosas.

Embora as referências escritas, que mencionam a antiga cidade de Chaul como um importante centro comercial da costa oeste da Índia, sejam abundantes, ainda não haviam sido identificadas evidências arqueológicas que comprovassem tal ocupação desde o início do período Histórico.

O levantamento sistemático do sítio portuário de Chaul teve por objetivo localizar e investigar a antiga ocupação na cidade alta e, assim, permitiu evidenciar a dinâmica das trocas comerciais entre a costa oeste e o interior da Índia, bem como entre o oriente e ocidente, na antiguidade. As etapas de campo, realizadas entre 2003 e 2005, incluíram a exploração e a escavação sistemática dessa área que, como veremos, apresentou evidências abundantes de depósitos habitacionais continuados por mais de dois mil anos.

Os sítios costeiros do oeste da Índia e do leste da África pertenciam a uma ampla rede de comércio marítimo existente, desde a antiguidade, no Oceano Índico. O antigo porto de Chaul possuía duas rotas comerciais terrestres principais que o ligavam ao planalto do Deccan: a primeira a nordeste, por meio do estreito Borghat, estava associada às grutas budistas de Chaul, Ramdharan, Nadsur, Karsamble e Gomasi, esse mesmo estreito ligava o porto de Kalliena (atual Mumbai) às grutas de Kārlī, Bhājā, Bedsā e Shelarvadi, até a cidade de Ter (Tagara, atual Pune); uma segunda via seguia a sudeste até a cidade de Mahad, passava pelo estreito Varandha por meio do qual também chegava a Ter, essa rota estava associada aos 
conjuntos monásticos de Kuda, Mahad, Kol e Shirval. ${ }^{12}$

Atualmente Chaul e Revdaṇḍā, embora considerados dois vilarejos distintos, estão localizados a menos de $3 \mathrm{~km}$ de distância, numa área densamente habitada. As antigas ocupações hindus, islâmicas e portuguesas, ali distribuídas, atualmente estão em ruínas e tomadas por uma densa plantação de coqueiros e bételes (areca) - base econômica da região -, que mantêm as vielas sombreadas e o solo úmido mesmo durante o inverno. Além dos lagos junto às montanhas, que fornecem irrigação abundante, a região sempre possuiu um grande número de poços d'água, que remontam ao período Sātavāhana. Um pequeno riacho, a cerca de 800 m da costa de Revdaṇ̣̂ā, corre para norte a partir do rio Kundạaīkā e forma a planície de inundação recente, densamente recoberta por arbustos e com extensão aproximada de $1 \mathrm{~km}$.

O local exato do antigo porto não havia sido encontrado devido ao assoreamento do antigo leito do rio Kuṇ̣alīkā e às flutuações recorrentes do seu estuário. Tais processos soterraram parte das edificações e tornaram-nas inoperantes, devido à mudança na posição do leito rio. Uma pesquisa recente foi desenvolvida abordando os aspectos geomorfológicos da região. ${ }^{13} \mathrm{O}$ estudo foi, fundamental à compreensão das modificações ocorridas nessa área costeira.

Durante a exploração da região de Chaul, realizada durante as três etapas de campo, foram documentados os vestígios arquitetônicos pertencentes às principais fases de ocupação que permaneceram preservados na superfície do sítio arqueológico. Os trabalhos foram acompanhados de registro fotográfico e mostraram-se fundamentais para compreensão do contexto em que esteve inserido o antigo sítio arqueológico de Chaul, antes de seu declínio.

(12) A associação peculiar entre as rotas comerciais e as grutas budistas é conhecida há mais de um século, o reverendo Abbott (1891:121) descobriu as grutas de Nadsur justamente porque estava convencido da existência de grutas budistas ao longo da rota que ligava Chaul ao interior. Ver também Codrington (1930;10-3); Kosambi (1955:51-2); Dehejia (1972:30-1); e sítios mais recentes em Marathe (2000) e Gogte (2004). Para um estudo mais aprofundado sobre as grutas budistas do Deccan, ver Aldrovandi (2006, V. II: 508-592).

(13) Realizada por Ghate (1990).
A fase de ocupação mais antiga do sítio aparece representada pelos três conjuntos de grutas budistas talhadas na rocha, associados ao período Sātavāhana, e localizados próximo à Chaul Alta, junto da antiga rota comercial que ligava a cidade portuária ao planalto do Deccan, mencionada anteriormente. Pouca informação pôde ser colhida da fase intermediária de ocupação de Chaul, período em que hindus e muçulmanos se sucederam no domínio da região e do qual poucos vestígios arquitetônicos restaram, devido às recorrentes disputas de poder. A maior parte dos vestígios preservados pertence à fase mais tardia, durante a qual Chaul esteve dividida entre a cidade alta - hindu ou islâmica, e a cidade baixa portuguesa. Tal período de ocupação é representado na Chaul Alta por monumentos que incluem templos hindus, mesquitas, tumbas e o forte de Rājkot. Na Chaul Baixa, encontram-se as ruínas do forte português, o Āgar Koț, cuja área foi inteiramente loteada e vendida a proprietários particulares, a quem cabe a decisão sobre a preservação ou destruição dos monumentos que estejam no terreno adquirido.

Tal levantamento, acompanhado da utilização de mapas e fotos de satélite, ${ }^{14}$ possibilitou a localização das áreas de habitação dos períodos mais remotos (Fig. 2). A antiga margem do rio Kuṇụalīkā, com aproximadamente $2 \mathrm{~km}$ de extensão ao longo do depósito de assoreamento mais antigo, era a área mais propícia à atividade portuária, uma vez que se encontrava protegida da força das marés e do vento costeiro (Figs. 3 e 4). Foi nesta região que as explorações sistemáticas foram iniciadas em 2003.

A antiga Chaul Alta, área de ocupação das dinastias hindus e muçulmanas, encontra-se a cerca de 1 km de distância do atual leito do rio Kuṇ̣alīiā. Dois depósitos decorrentes do assoreamento do rio puderam ser observados: um antigo e estabilizado, sobre o qual foi construído o antigo porto e, atualmente, observado como uma densa área de plantação de coqueiros; e um mais recente, 1,5 m abaixo do nível do depósito mais antigo e que forma a planície de inundação moderna. As pesquisas revelaram que o depósito antigo ocupa

(14) Trabalho realizado com a colaboração do prof. Bruno Marcolongo, Diretor de Pesquisa do CNR-IRPI e Remote Sensing, Universidade de Padova, Itália. 
GOGTE, V.D.; ALDROVANDI, C.E.V. A Simylla do Périplo do Mar Eritreu: escavação arqueológica do antigo sítio portuário de Chaul na costa oeste de Mahārāșțra - Índia. Rev. do Museu de Arqueologia e Etnologia, São Paulo, 15-16: 247-269, 2005-2006.

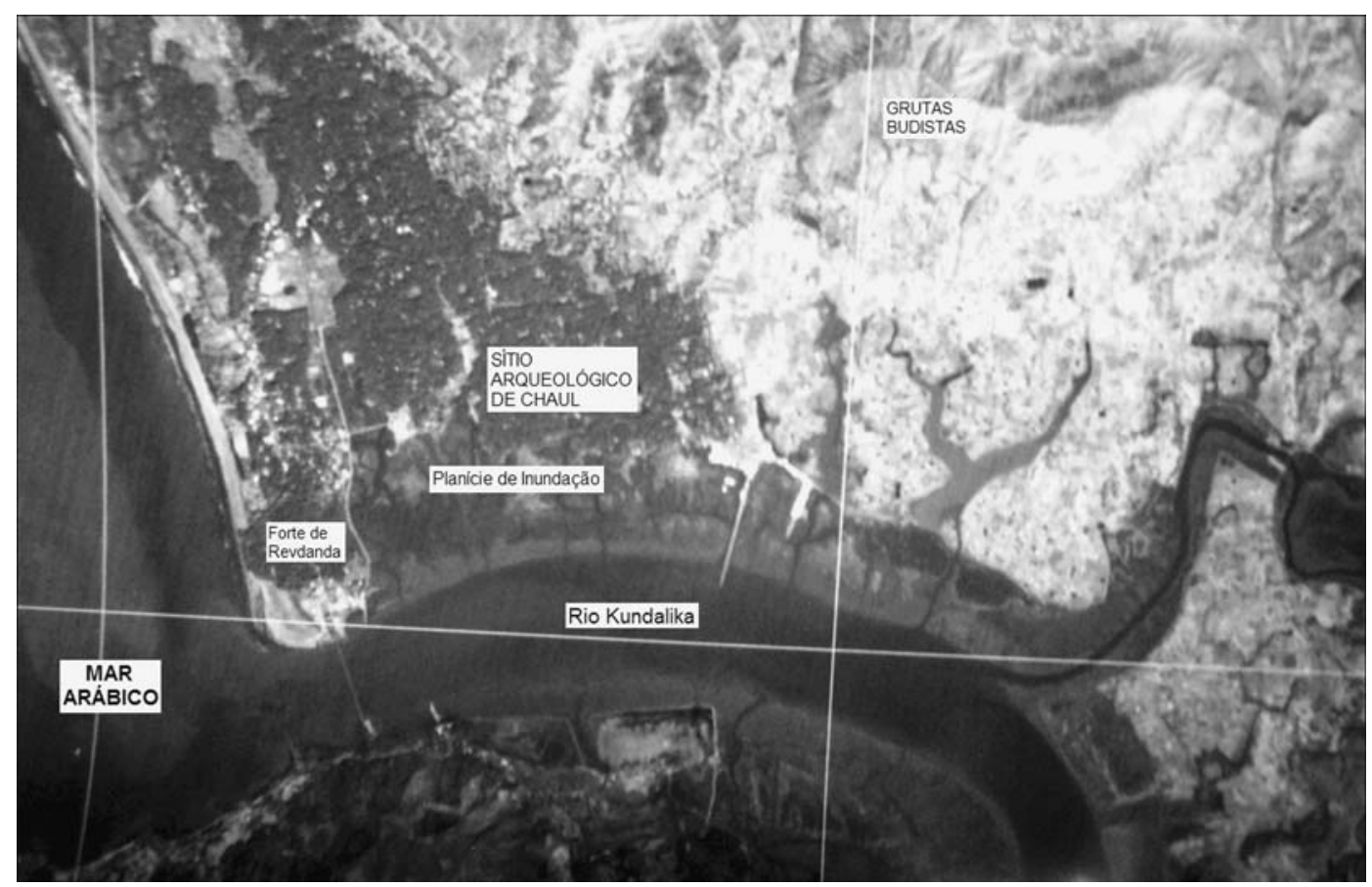

Fig. 2 - Imagem de satélite da região de Chaul (Gogte 2003).

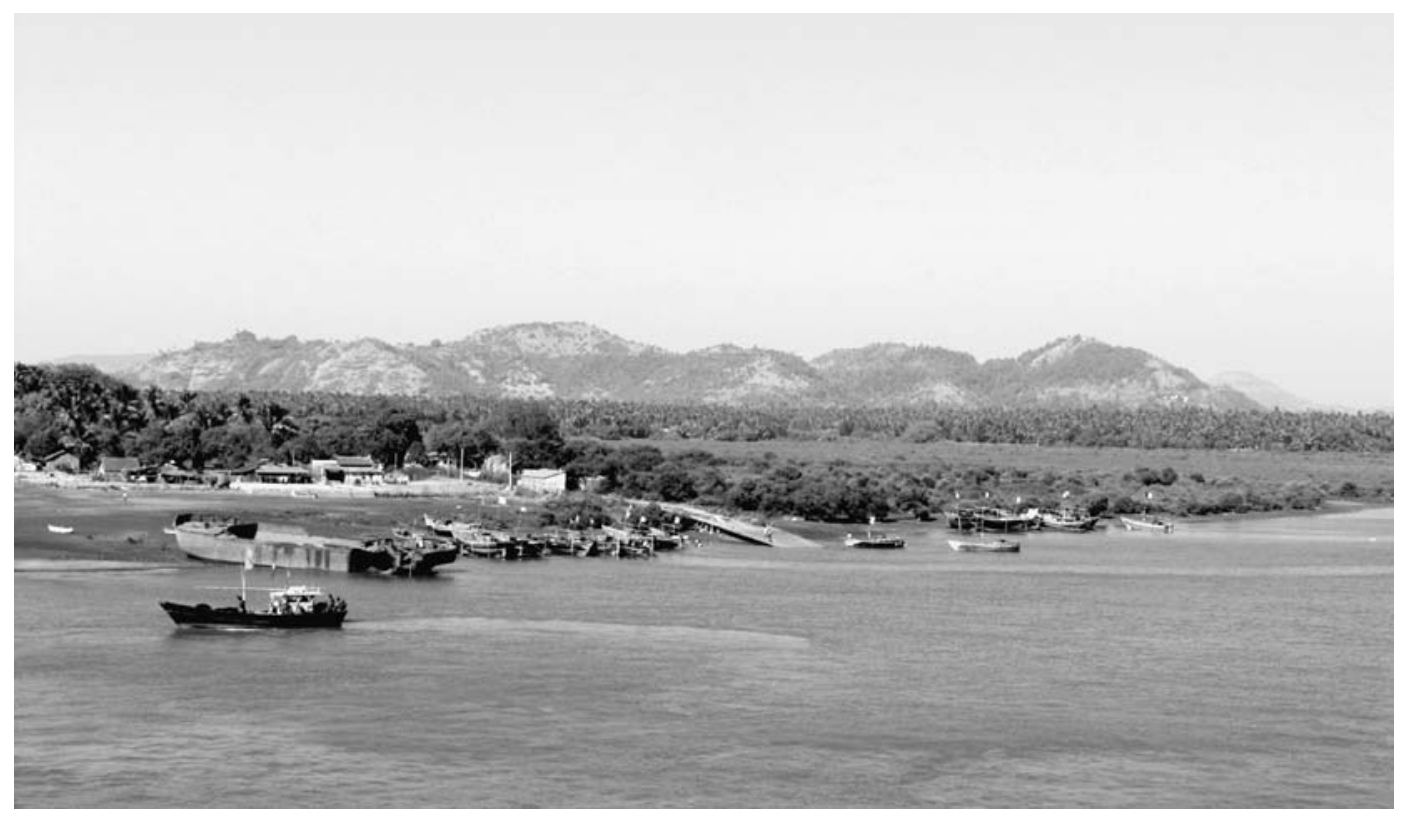

Fig. 3 - Vista geral de Chaul a partir da embocadura do rio Kundalikā. O rio aparece em primeiro plano; em seguida uma faixa horizontal mais clara indica a planície de inundação mais recente; a faixa posterior mais escura é a plantação de coqueiros na área em que se encontra o sítio arqueológico; a seguir estão as montanhas ao fundo, nas quais estão as grutas budistas de Chaul (foto: Aldrovandi 2005). 


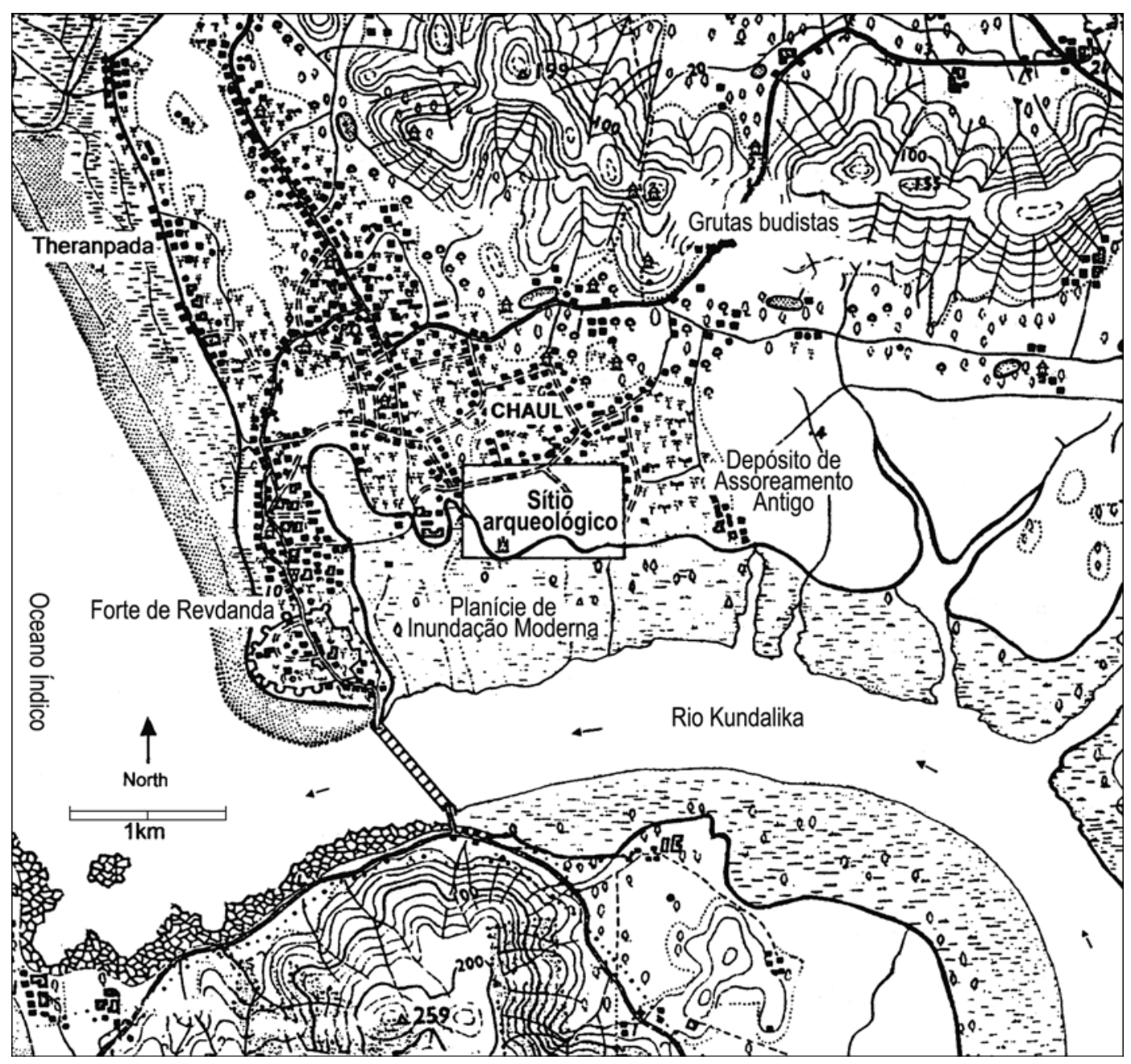

Fig. 4 - Mapa da região de Chaul (Gogte 2003).

uma faixa com cerca de $10 \mathrm{~km}$ ao longo da margem do rio e está logo acima do estrato pertencente ao Holoceno.

Os vestígios arqueológicos encontram-se distribuídos por uma área de aproximadamente 1,2 km de extensão, que forma uma faixa irregular na direção lesto-oeste junto à porção final do lado sul da antiga margem do rio - no depósito de assoreamento antigo. A antiga ocupação penetra na direção norte por cerca de $400 \mathrm{~m}$, a partir dos quais a freqüência do material arqueológico de superfície decresce consideravelmente.

As ruínas do muro de proteção ou ancoradouro, junto à área de ocupação, podem ser observadas ao longo do que foi a antiga margem do leito do rio Kunḍalīkā. Tal construção possui cerca de 1 m de largura e uma extensão aproximada de $800 \mathrm{~m}$ que é, por vezes, interrompida junto aos locais em que o muro foi soterrado pela planície de inundação. As paredes foram construídas com pedras chatas de tamanho irregular, aparentemente, sem argamassa. A face que costumava estar voltada para o lado do rio está bastante desgastada. A distância entre tais muros de proteção e o atual leito do rio, área da planície de inundação moderna, chega a ter $1 \mathrm{~km}$ de extensão. Num dos pontos desse muro (N18³3'11.3", EO7256’27.1") é possível observar uma estrutura perpendicular, construída com blocos de basalto e medindo cerca de $3 \mathrm{~m}$ de largura, que segue em direção ao antigo rio e, 
atualmente, desaparece a aproximadamente $20 \mathrm{~m}$ na planície de inundação. Essa estrutura, semelhanteà encontrada junto ao grande edifício em ruínas no Forte Rājkoṭ (N18³3'11.1", EO7256’35.9"), provavelmente foi um ancoradouro ou cais para embarcações de menor porte. Um levantamento preliminar dessa área junto ao antigo muro de proteção do porto da Chaul Alta evidenciou a presença de grande quantidade de material cerâmico. O material aflora profusamente na superfície do terreno, que é densamente cultivado por plantações de coqueiros e bétele.

\section{II.1. Resultados da pesquisa arqueológica}

As primeiras evidências em contexto arqueológico dos períodos mais remotos de ocupação da área em que se supunha ter sido a antiga Chaul Alta foram obtidas inicialmente nas covas que estavam sendo abertas entre os coqueirais para construção de poços. ${ }^{15}$ Esse levantamento preliminar, realizado em 2003, forneceu evidências concretas do período Sātavāhana (c. 230 a.C. - 230 d.C.) atestadas pela cerâmica, poços de anéis cerâmicos, moedas, contas e braceletes de vidro encontrados durante a abertura de um dos poços. Os períodos mais tardios aparecem representados por vestígios materiais dos Śilahārā (c.1000-1200 d.C.) e Bahamani (c. $1400-1600$ d.C.). ${ }^{16}$

(15) O poços na região do Konkan são geralmente escavados no verão, as covas são abertas com $4 \mathrm{~m}$. de largura, até que se chegue ao nível do lençol freático, encontrado junto ao depósito arenoso endurecido, conhecido na região como kara ou karal.

(16) Como observou Gogte (2003:69) o material arqueológico associado aos Sātavāhana e às dinastias dos períodos subseqüentes recorreu nas seis áreas em que poços estavam sendo escavados, locais distantes o suficiente para indicar que a ocupação Sātavāhana não se limitou a uma pequena área, mas acompanhou a extensão de terra utilizada pelos assentamentos posteriores. A estratigrafia dos depósitos habitacionais em Chaul é semelhante àquelas encontradas em Kolhapur (Sankalia and Dikshit 1952), em que os níveis pós-Sātavāhana foram classificados como Sātavāhana-tardio (c. 500-1400 d.C.) e Bahamani (c.1400-1600 d.C.). O período Bahamani em Kolhapur se encontra associado ao período muçulmano-marāthā dos sítios de Nasik e Nevasa (Sankalia and Deo 1955; Sankalia et al. 1960). Assim a nomenclatura utilizada em Chaul segue a seguinte uniformização: 1. Período Medieval Inicial (500-1300 d.C.), geralmente chamado Sātavāhana-tardio, pós-Sātavāhana e Śilahārā; 2. Período Medieval Tardio (1300-1700 d.C.), que inclui os períodos
Duas etapas de campo subseqüentes, em 2004 e 2005 , foram realizadas com o objetivo de escavar as áreas em que a freqüência do material arqueológico de superfície mostrou-se mais elevada. A etapa de campo 2004 ocorreu durante o mês de maio; a etapa 2005 ocorreu entre os meses de janeiro e fevereiro. Nessas expedições foram escavadas quatro áreas distintas do sítio, duas mais próximas do antigo muro de proteção junto à borda da planície de inundação (CHL-P e CHL-D) e outras duas na área mais elevada do sítio (CHL-V e CHL-A).

Uma quantidade expressiva de material arqueológico foi recuperada durante as etapas de campo realizadas em Chaul. Por questões de espaço, no presente artigo serão destacadas apenas as tipologias que auxiliam a compreensão da dinâmica e cronologia do sítio.

\section{II.1.1. Cerâmica}

Chaul apresentou uma grande quantidade de fragmentos cerâmicos, compostos por uma ampla gama de tipos cerâmicos. A cronologia do sítio aparece claramente refletida na estratigrafia cerâmica. Embora ainda esteja sendo estudada, a cerâmica encontrada pode ser classificada entre os tipos autóctones e os de origem estrangeira que, por sua vez, foram sub-divididos entre aqueles que pertencem às regiões a oeste da Ásia e aos de origem chinesa. ${ }^{17}$

Bahamani e muçulmano-marāthā de diferentes sítios. Na verdade a nomenclatura usual do Período Histórico Inicial (250 a.C. - 500 d.C.), geralmente utilizada na Índia, poderia ter sido utilizada para designar o período Sātavāhana em Chaul, mas como muitos aspectos da cultura material são características específicas do período Sātavāhana no oeste da Índia, o mesmo foi utilizado para descrever esta parte inicial do Período Histórico.

(17) O material vem sendo pesquisado por Rukshana Nanji, doutoranda do Deccan College. Entre a cerâmica estrangeiras temos até agora identificadas: Sassanian-Islamic Turquoise Glazed Ware; Glazed Pink Ware; Hatched Sgraffiato Ware; Glazed Buff Ware; Buff Ware; White Slipped Pink Ware; Eggshell Ware; White Glazed Ware; Red Slipped Pink Ware; Monochrome Ware. Os tipos cerâmicos chineses incluem: Porcelana (lisa); Porcelana (azul e branca); Celadon; Stoneware (faiança); Glazed Gray Ware. Os tipos autóctones estão representados pelas: Slipped Red Ware; Slipped Grey Ware; Chocolate Slipped Ware; Red Ware; Compact Red Ware; Red Polished Ware; Black and Red Ware; Mica Washed Red Ware; Slipped Black Ware; Black Polished Ware; Monochrome Glazed Ware. 
O nível estratigráfico inferior apresentou fragmentos da Cerâmica Preta e Vermelha (BRW Black and Red Ware) e também da Cerâmica Preta Polida (BPW - Black Polished Ware), encontrados entre os vestígios correspondentes ao nível estratigráfico 5, anterior à camada arenosa estéril 6. Esses dois tipos cerâmicos são muito freqüentes na Índia antiga e diretamente associadas ao período da Dinastia Maurya (séculos III-II a.C.) e à região de Magadha, na planície do Ganges. $\mathrm{O}$ uso da cerâmica BPW teve início por volta do ano 500 a.C. e foi descontinuado por volta do ano 200 a.C. o que a torna um vestígio importante na datação de sítios arqueológicos da Índia antiga. A cerâmica BPW é geralmente encontrada em baixa quantidade, o que faz pensar que possivelmente se tratava de um item luxuoso e importado da região do Ganges. Fragmentos desse tipo cerâmico foram encontrados, com freqüência, em escavações arqueológicas em áreas distantes da bacia gangética, nas quais aparecem associados à cerâmica BRW. A existência desses vestígios em Chaul é de grande interesse pois evidencia o contato entre a sua região de origem e a costa oeste do subcontinente indiano, uma indicação de possíveis trocas comerciais durante a antiguidade. A ocupação habitacional presente no nível estratigráfico 5 de Chaul pôde, por isso, ser associada ao período Maurya.

No nível estratigráfico associado ao período Sātavāhana foram encontrados fragmentos de Cerâmica de Engobo Vermelho (SRW - Slipped Red Ware) cujo uso é atestado desde o período Maurya e a origem associada à planície gangética. ${ }^{18}$ Tal gênero cerâmico pode ter sido trazido à costa oeste por mercadores ou pelos monges budistas que vieram do norte da Índia nos primeiros séculos antes da era Cristã, e cuja presença está confirmada pelas grutas budistas próximas ao sítio arqueológico de Chaul. Esse tipo cerâmico aparece associado à Cerâmica Polida Vermelha (RPW Red Polished Ware). Embora esta tenha sido encontrada, em vários sítios do Golfo Pérsico e do

(18) Gogte (1996; 2002) observou que esse tipo cerâmico foi, durante longo tempo, confundido com exemplares tardios provenientes da costa africana, mas análises químicas confirmaram que ele está associado mineralogicamente à cerâmica e à argila da Planície do Ganges, no norte da Índia.
Oceano Índico, associada à cerâmica islâmica do início do Período Histórico e, em alguns casos, à cerâmica chinesa, a Cerâmica Vermelha Polida encontrada em Chaul aparece, na Índia, associada a níveis estratigráficos relativos ao século I d.C., assim, ela é utilizada como marco cronológico e para comprovar contatos comerciais entre tais regiões. Análises mineralógicas mostraram que esse tipo cerâmico de textura uniforme é composto de tempero idêntico à argila encontrada numa região da costa oeste indiana identificada como Ariaque no Périplo do Mar Eritreu (ver Gogte 2002).

Outro tipo cerâmico bastante característico do período Sātavāhana (Fig. 5) é representado pelos vasos e bases de copos cônicos e com base estreita, cujas laterais apresentam marcas circulares corrugadas, tempero de argila vermelha com fábrica de textura grosseira. Em Chaul tais tipos cerâmicos pertencem ao nível estratigráfico (4) associado aos séculos I-II d.C. e ainda estão presentes naquele relativo aos séculos V-VII d.C. Alguns desses copos foram encontrados em Chaul, ${ }^{19}$ associados a um crânio humano e a fragmentos de ânforas romanas, que serão tratados mais à frente.

O horizonte cerâmico seguinte (3) em Chaul começa a apresentar evidências de cerâmica vitrificada de origem estrangeira e peças de faiança chinesa grosseira, possivelmente indicando o início da fase de intensa atividade comercial com o leste asiático que se seguiu. ${ }^{20}$ A porcelana chinesa é 0 tipo cerâmico mais abundante em Chaul e pertence ao período da dinastia Ming, do século XIV d.C. O celadon ou qingzhi é o segundo tipo de cerâmica chinesa mais recorrente no sítio de Chaul. Esse material começou a ser produzido durante o

(19) São eles: 1) o primeiro com $18 \mathrm{~cm}$. de diâmetro na borda, $4,5 \mathrm{~cm}$ na base e $8 \mathrm{~cm}$ de altura; 2 ) o segundo com $12 \mathrm{~cm}$ de diâmetro na borda, $5,8 \mathrm{~cm}$ na base e $8 \mathrm{~cm}$ da altura; 3) o terceiro com $12 \mathrm{~cm}$ de diâmetro da borda, $4 \mathrm{~cm}$ na base e 4,5cm de altura. O primeiro tipo de copo é recorrente em todos os sítios do período Sātavāhana no oeste da Índia. (20) A faiança vitrificada, a porcelana azul e branca e o celadon chineses, associados aos níveis estratigráficos mais tardios, aparecem também em grandes quantidades espalhados pela superfície do sítio de Chaul, devido à fitoturbação ocasionada pelo cultivo intensivo da região. $\mathrm{O}$ cultivo do solo, associado à natureza arenosa do mesmo, foi responsável, em alguns casos, pela intrusão do material arqueológico nos níveis estratigráficos inferiores. 


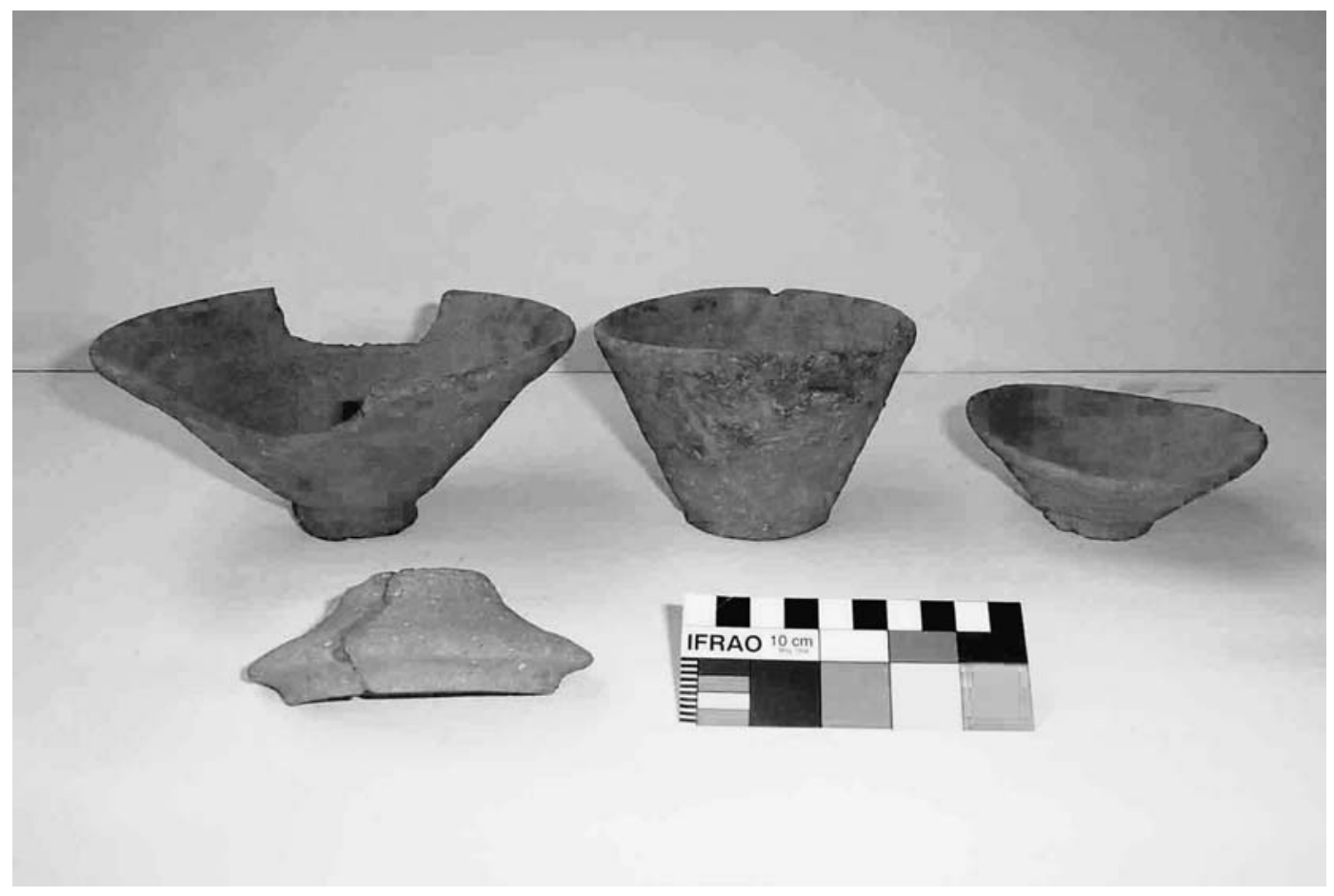

Fig. 5 - Cerâmica Sātavāhana com fábrica de textura grosseira (Gogte 2003).

período Song, no século X d.C., e continuou durante o período Yuan.

A tipologia da cerâmica vitrificada islâmica, recorrente a partir do século XIV, inclui vasos grandes para armazenamento de cereais, potes e vasilhas de tamanhos variados, pratos e copos. Esse tipo cerâmico apresenta diferentes cores, especialmente azul turquesa, verde, amarelo, marrom e tons arroxeados; a maior parte possui pintura monocroma, mas alguns fragmentos evidenciam desenhos geométricos ou florais executados em traços livres, geralmente na cor preta. O gênero cerâmico Sgraffiato (ver Bienkowski 1996:85), caracterizado por uma mescla de tons de verde, amarelo e vermelho com pseudo-escrita incisa, aparece com freqüência nos níveis estratigráficos superiores de Chaul e pertence ao período islâmico Mamluk - 1250-1516 d.C., sendo, portanto, contemporâneo da porcelana Ming. O gênero cerâmico Silhouette, de origem islâmica e anterior às tipologias mencionadas acima, também foi encontrado. Sua importância reside no fato de possuir datação precisa e possibilitar estabelecer uma cronologia mais acurada. Esta cerâmica é proveniente da região do Irã e Iraque e datada dos séculos XI e XII d.C. Trata-se de um tipo de cerâmica vitrificada com fundo azul turquesa e desenho linear preto.

Fragmentos de uma cerâmica imitação da porcelana Ming, produzida no período islâmico, também foram encontrados na superfície e níveis estratigráficos superiores, o fragmento feito de cerâmica de fábrica mais grosseira recebia um acabamento externo vitrificado nas cores correspondentes à porcelana chinesa - azul e branco. ${ }^{21}$

\section{II.1.2. Poços de anéis cerâmicos}

Uma grande quantidade de fragmentos de poços de anéis cerâmicos - ringwells, foi encontrada em Chaul. Eles figuram de modo recorrente durante a abertura de covas para construção de poços modernos. Os ringwells eram elaborados

(21) Rukshana Nanji nos informou, durante a etapa de campo, que os muçulmanos nunca foram capazes de produzir a porcelana e, por isso, recorriam a essa imitação. 
por meio da sobreposição e encaixe de grandes anéis cerâmicos, que partiam da base da cova escavada até a superfície do terreno. Há alguns anos, acreditava-se que os ringwells fossem apenas fossas sépticas, mas a descoberta dessas estruturas em outros sítios arqueológicos do Deccan e Konkan, que alcançavam os lençóis freáticos, esclareceu e ampliou o conhecimento a seu respeito. ${ }^{22}$ Sabe-se que eles começaram a ser construídos nessas regiões durante o período Sātavāhana tardio, por volta do século III d.C. Em Chaul, a quadra CHL-V apresentou dois desses $\operatorname{poços}^{23}$ que atravessavam o karal e chegavam ao lençol freático (Fig. 6). O nível estratigráfico em que se encontra o anel cerâmico superior do Poço 1 , nesta quadra, permite inferir que a utilização desse tipo de estrutura se prolongou até os períodos mais tardios, pelo menos até os séculos XIII e XIV d.C., pois é compatível com a cerâmica sgraffiatto e porcelana Ming associadas, o que indica uma continuidade, até então desconhecida, na produção e uso desse tipo de estrutura.

\section{II.1.3. Edificações}

Durante a etapa de campo de 2005 foi encontrada na quadra CHL-A uma estrutura de pedra e, logo abaixo, uma base murada de tijolos com tamanho semelhante aos utilizados no período Sātavāhana, de dimensões uniformes (40X27X8cm). A construção acompanhava a direção norte-sul e a altura da base de tijolos era de $85 \mathrm{~cm}$, sobreposta a uma fundação sólida de pedras com $1 \mathrm{~m}$ de altura. O material associado incluiu cerâmica dos séculos VII ao XII d.C. Uma moeda Kṣatrapa de chumbo foi encontrada na fundação. Fragmentos de Cerâmica Vermelha e Negra (BRW) foram

(22) Esses poços recorrem em sítios da costa leste como Nevasa, Bhon, Sanjan (ver Sankalia et al 1960; Gupta et al 2004), bem como em Taxila, Mathurā, Hastinapur,

Kausambī e Rajghat no norte da Índia, e Tamluk, Mangalkot, Itakhola e Pakhanna, em Bengala (Pande 1964; Joshi 1990; Datta 2001). A origem mesopotâmica dos ringwells foi sugerida por Pande (1964), cuja existência data do quarto milênio a.C.; a tradição foi mantida durante o período Aquemênida (Joshi 1990) e teria sido trazida à Índia nessa época.

(23) Os anéis possuem cerca de 30 a $50 \mathrm{~cm}$ de altura, $75 \mathrm{~cm}$ de diâmetro e $3 \mathrm{~cm}$ de espessura, a borda superior é mais larga, com c. $6 \mathrm{~cm}$ O poço 1 possuiu cerca 3,5m de altura.

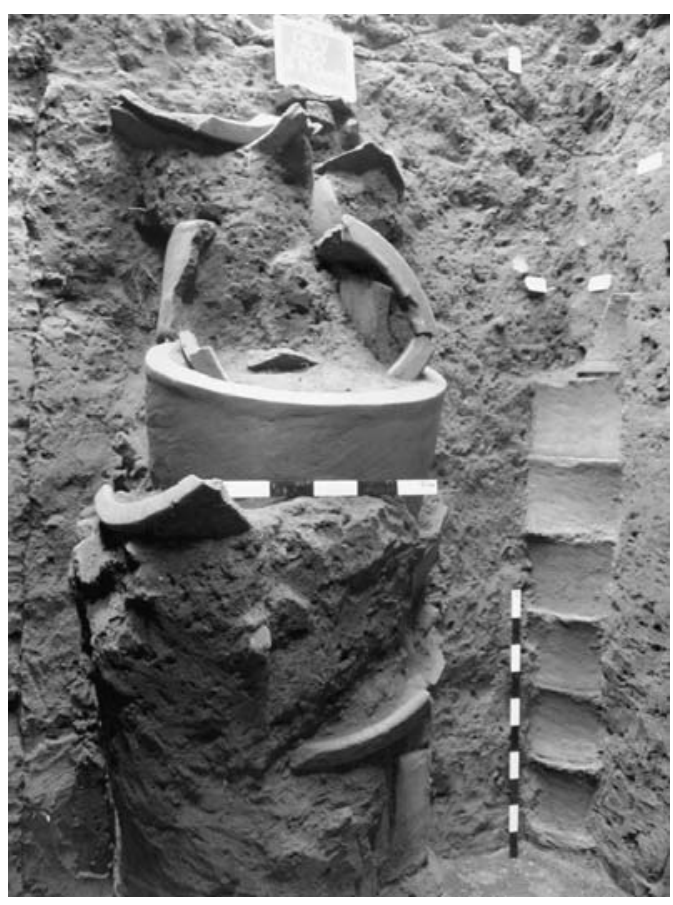

Fig. 6 - Poços de anéis cerâmicos na quadra CHL$V$ (foto: Aldrovandi 2005).

coletados no nível estratigráfico inferior em uma cova calcificada aberta no solo arenoso estéril.

\section{II.1.4. Vidro}

Uma grande quantidade de material vítreo foi recuperada durante as escavações, em especial contas e braceletes de vidro, assim como fragmentos de pequenas vasilhas ou garrafas e, em menor número, anéis simples. A escavação da quadra CHL-V permitiu evidenciar um centro medieval de produção de contas de vidro. O principal tipo de conta encontrado em Chaul são as miçangas coloridas, chamadas Indo-Pacific Glass Beads ou Trade Wind Beads (Fig. 7). Tais contas são pequenas e arredondadas com diâmetro variado, entre 1,5 a 5mm, e encontradas nas seguintes cores: preto, azul escuro, azul claro, azul-esverdeado, verde, amarelo e vermelho. Elas eram manufaturadas na Índia e exportadas desde o ano 200 a.C. até o século XVII d.C. Essa tipologia foi encontrada em sítios arqueológicos em toda a costa do Oceano Índico, no sul e leste da África. As contas eram transportadas por navios de comerciantes árabes, 


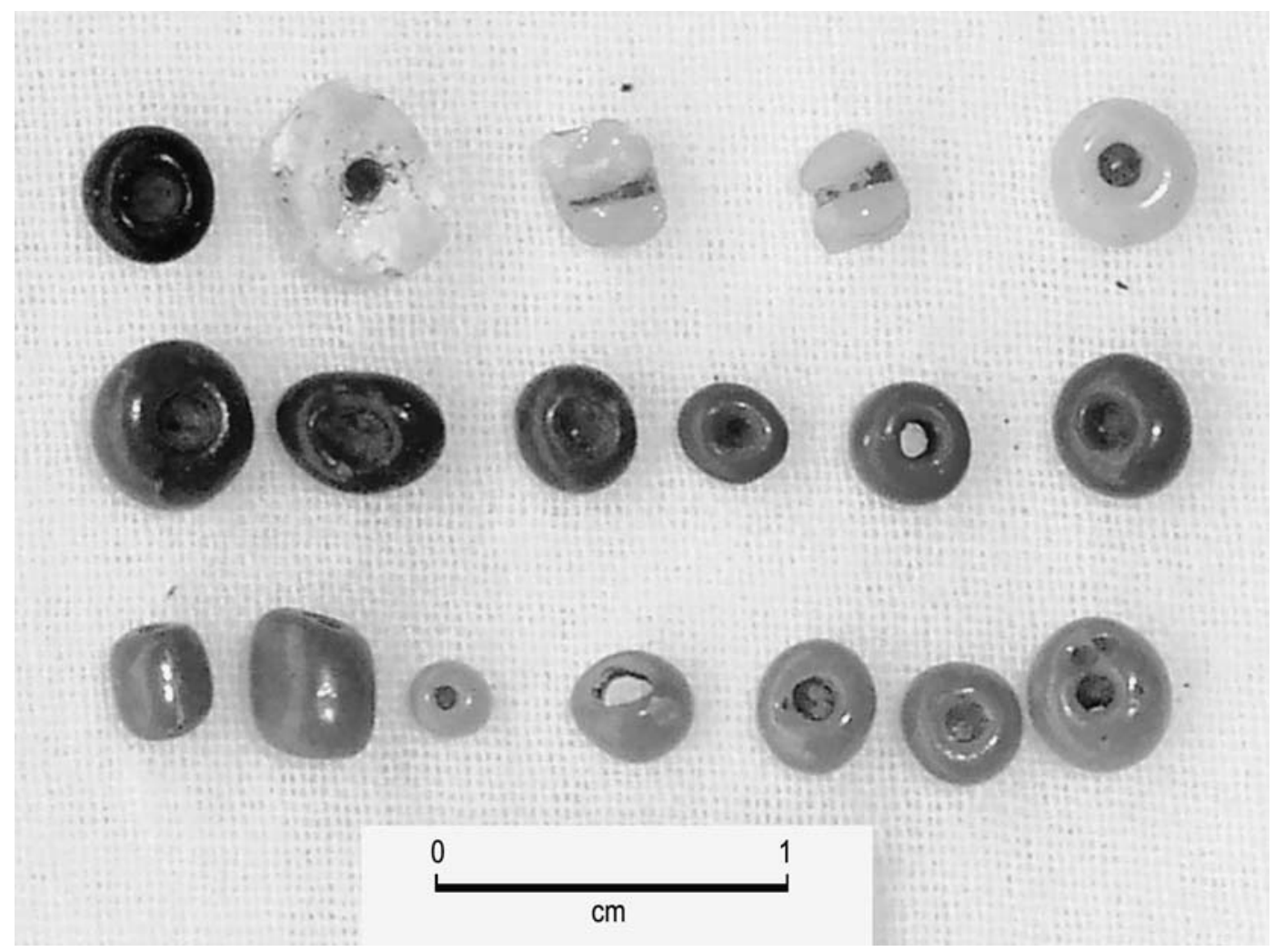

Fig. 7 - Contas: Indo-Pacific Glass Beads (Gogte 2003).

indianos e chineses. Há narrativas que mencionam o monopólio de Chaul na produção de contas de vidro que eram exportadas para África durante o período mais tardio de ocupação, entre os séculos XV a XVIII d.C. ${ }^{24}$

Outros tipos de contas de vidro também foram encontrados em Chaul, embora em menor quanti-

(24) Ver Dubin (1995:184); e Maharashtra State Gazetteer (1964:726). O material cerâmico, encontrado em sítios da costa oeste indiana e leste africana, confirma a existência de interação e o comércio marítimo desde o século VIII d.C. Durante as explorações em Chaul foram encontradas espécies arbóreas provenientes da costa leste da África, que reforçam a evidência de contatos comerciais (Gogte 2003). Entre elas, um Bao Bab (Adasonia digital L.), chamado em Mahārāshtra de Ghorakh Chinch, encontrado na base da montanha em que estão as grutas budistas e cujas dimensões sugerem uma idade superior a oitocentos anos. Outra árvore bastante comum na região de Chaul e típicamente africana é a árvore da fruta pão (Artocarpus communis). dade. Dentre as mais expressivas estão as Melon Beads (Fig. 8), caracterizadas pelo formato de melão e cor azul-escura com incisões no comprimento. Esse tipo de conta é característico do período Sātavāhana e também foi encontrado nos sítios arqueológicos de Kholapru, Chandravalli, Kondapur e Karad (ver Sankalia e Dikshit 1952:102), bem como em Arikamedu (ver Wheeler et al. 1946: pr.XXXIII; Stern 1991:119). Embora em menor número, existe uma quantidade considerável de contas lapidadas em pedras semi-preciosas (cristal, calcedônia, cornalina, ametista e granada) e terracota.

Os braceletes de vidro possuem tipologia variada. Dentre eles estão os azul escuros, semicirculares, encontrados em depósitos do início do período histórico em Nevasa (Sankalia et al. 1960). Os braceletes chatos, com camadas amarelas e laranjas incisas e com contas ao redor; e outros translúcidos com camada superior esverdeada e inferior amarelada, pertencem ao período medieval tardio e foram também encontrados em 


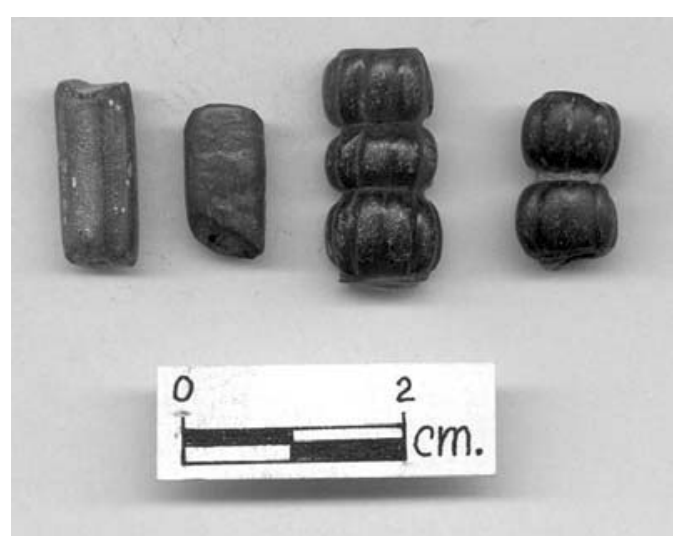

Fig. 8 - Contas: Melon Beads (Gogte 2003).

Kolhapur (Sankalia e Dikshit 1952:112). Também foram encontrados pequenos nódulos de escória e fragmentos de vidro fundido que, aparentemente, restaram da fabricação desses materiais.

\section{II.1.5. Metais}

Os objetos de ferro encontrados em Chaul são principalmente cravos, espátulas, pinças, pontassecas, ponta de seta, cinzéis, facas e lâminas, anéis e rolos de arame; alguns instrumentos, ferramentas e fragmentos não identificados. Alguns fragmentos de escória de ferro também são encontrados na superfície do sítio. Um deles estava fundido à porcelana chinesa. Parece provável que os instrumentos em ferro estejam associados ao período medieval tardio e, possivelmente, à manufatura de colares de contas de vidro. Também foram encontrados alguns objetos em cobre em menor quantidade, como tigelas oxidadas, um anel completo, pedaços de arame e fragmentos não identificados.

As moedas recuperadas no sítio pertencem aos períodos Sātavāhana, Marāthī e Bahamani (ver tabela em Gogte 2003:71). Durante a etapa 2005, foram encontradas cinco moedas na quadra CHL-B, todas de cobre e oxidadas, o que impossibilitou uma identificação preliminar; a quadra CHL-C forneceu exemplares em melhor estado de conservação. ${ }^{25}$

(25) As moedas encontradas durante essa etapa de campo vem sendo analisadas pelo prof. Abhijit Dandekar, especialista em numismática e paleografia do Deccan College.

\section{II.1.6. Material lítico}

Na etapa de campo de 2003 foram escavados dois almofarizes-pedestais - saddle quern, com quatro pernas: um maior, associado ao período Sātavāhana (48X18,5X20,5cm), e um menor, do início do período Medieval (42X11,5X16,5cm), ambos de basalto; exemplos semelhantes foram encontrados em Kolhapur (ver Sankalia e Dikshit 1952:130). Um terceiro exemplar, sem pernas e com uma plataforma quadrada como base foi encontrado próximo da superfície, provavelmente datado do período Medieval Tardio; um almofariz similar foi encontrado em Paturda, mas associado ao século VIII d.C.(Gogte 2003:72). Alguns fragmentos de vasilhas de pedra foram encontrados durante a exploração de superfície e nos níveis estratigráficos superiores da quadra CHL-D.

\section{II.1.7. Vestígios humanos}

O crânio humano encontrado em boas condições de preservação e associado ao nível estratigráfico do período Sātavāhana pertenceu a um individuo adulto do sexo masculino, com aproximadamente 35 anos de idade. ${ }^{26}$ Um sepultamento humano foi encontrado na etapa de campo 2005, durante a escavação da quadra CHL-B, a 1,36m de profundidade, junto ao canto SE do quadrante e próximo do perfil sul deste mesmo. A disposição do enterramento seguia orientação norte-sul, o corpo fletido em decúbito lateral direito; o topo da cabeça ao norte; o rosto voltado para oeste (Fig. 9). ${ }^{27} \mathrm{O}$ enterramento difere

(26) A análise foi realizada pelos professores S.R Walimbe e V. Mushrif, do laboratório do Deccan College, resultados publicados por Gogte (2003:72-3). (27) Os membros inferiores se encontravam no quadrante que se estendia a partir do perfil sul e, por isso, não puderam ser recuperados. Durante a escavação do esqueleto cujas dimensões somavam aproximadamente $18 \mathrm{X} 35 \mathrm{~cm}$, ficou evidenciada a cova do enterramento, de formato quase retangular e cujas dimensões aproximadas somam 46X62cm. O solo da cova era friável e de tonalidade amarelada, foram encontrados apenas alguns cacos cerâmicos associados aos restos humanos. Essa cova encontra-se no nível estratigráfico 3 e termina junto ao estrato 2 . Todos os 32 dentes estavam presentes o que indica que se trata de um indivíduo adulto, a abrasão presente nos molares pode ser decorrente da alimentação proveniente do mar. Os metacarpos e falanges encontravam-se em posição que indica que estiveram curvados para dentro. 
dos padrões normalmente encontrados, que seriam: a cremação, entre os hindus; e a inumação em posição estirada frontal, entre os muçulmanos. A área adjacente à quadra CHL-B possui um cemitério islâmico do período Medieval Tardio, em que se encontra uma grande quantidade de lápides de pedra espalhadas por toda parte, mas com maior recorrência na porção sul junto à quadra CHL-B.É possível que o sepultamento tenha sido realizado por tribais, mas é necessária uma análise mais aprofundada das formas de deposição praticadas entre os tribais da região, que acrescida dos dados provenientes das análises osteológicas permitirão uma interpretação mais precisa.

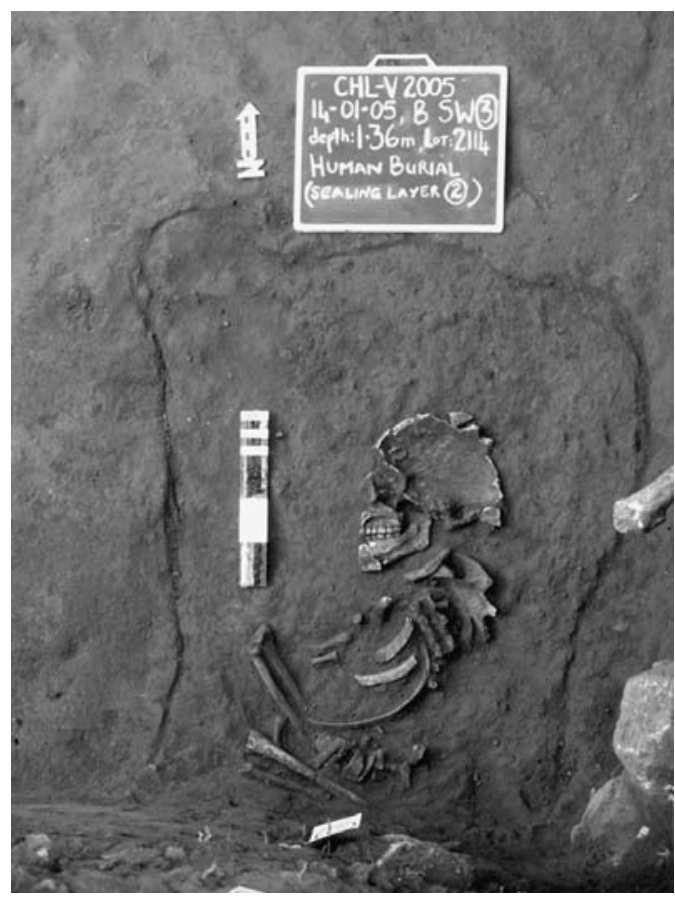

Fig. 9 - Enterramento na quadra CHL-V (foto: Aldrovandi 2005).

\section{II.1.8. Ânforas romanas}

Entre os fragmentos de ânforas romanas escavados em Chaul (Fig. 10), três foram identificados com os tipos Dressel 2-4 ou Will 12:

- Uma alça dupla, tempero arenoso avermelhado, com inclusões negras, pequenos fragmentos de mica e superfície creme. A alça é idêntica àquela encontrada em Nevasa (n.4420 A, nível
4). Também é semelhante à categoria 'b’ de ânforas Dressel 2-4 encontradas em Qana no Yemen. ${ }^{28}$

- Uma base, tempero arenoso creme avermelhado, inclusões negras, pequenos fragmentos de mica e superfície creme. As características conferem com a ânfora de alças duplas encontrada em Nevasa (no. 4426, nível 4). Também se assemelha em parte com as categorias 'a' e b' de ânforas Dressel 2-4 encontradas em Qana.

- Fragmento do corpo da ânfora, tempero coloração rosada sem inclusões mas com um pouco de mica. Superfície com camada creme esbranquiçada. Características semelhantes a um fragmento de alça dupla encontrado em Nevasa (no.439, nível 4) e um fragmento de ânfora romana encontrado em Junnar, Mahārāsțra. Confere com a categoria 'a' das ânforas Dressel 2-4 de Qana.

Os fragmentos de ânfora Dressel 2-4 encontrados em Chaul são semelhantes àqueles escavados em Nevasa, o que permite supor que a chegada desses recipientes até esta cidade tenha ocorrido pelo porto de Chaul, via Junnar e Kārlī, por meio do estreito Borghat. ${ }^{29}$ A localização do sítio portuário de Chaul numa área intermediária das rotas marítimas entre o ocidente e oriente colocou-o numa posição comercial estratégica. Qana estava a uma distância menor de Chaul que dos demais portos da costa oeste da Índia. O Périplo do Mar Eritreu menciona que os navios que chegavam à Índia primeiro ancoravam em Barygaza, em seguida, passavam por Souppara e Kalliena, até chegar a Chaul. Durante o início do seculo I d.C. as disputas entre os Kșatrapa de oeste, que governavam o Gujarate e

(28) Sedov (1998) datou esses tipos de ânfora entre os séculos I e III d.C. e Will (1992) datou ânforas semelhantes entre os séculos I a.C. e I d.C. O sítio de Qana, na saída do Mar Vermelho, pode ter sido uma importante escala durante essa época para as embarcações que seguiam até Chaul e os demais portos da costa oeste da Índia.

(29) Nevasa foi um dos maiores sítios históricos do período Sātavāhana escavado pelo Deccan College (Sankalia et al 1960), e cujos contatos comerciais com o mundo romano e o Golfo Pérsico foram confirmados pelos vestígios cerâmicos. 

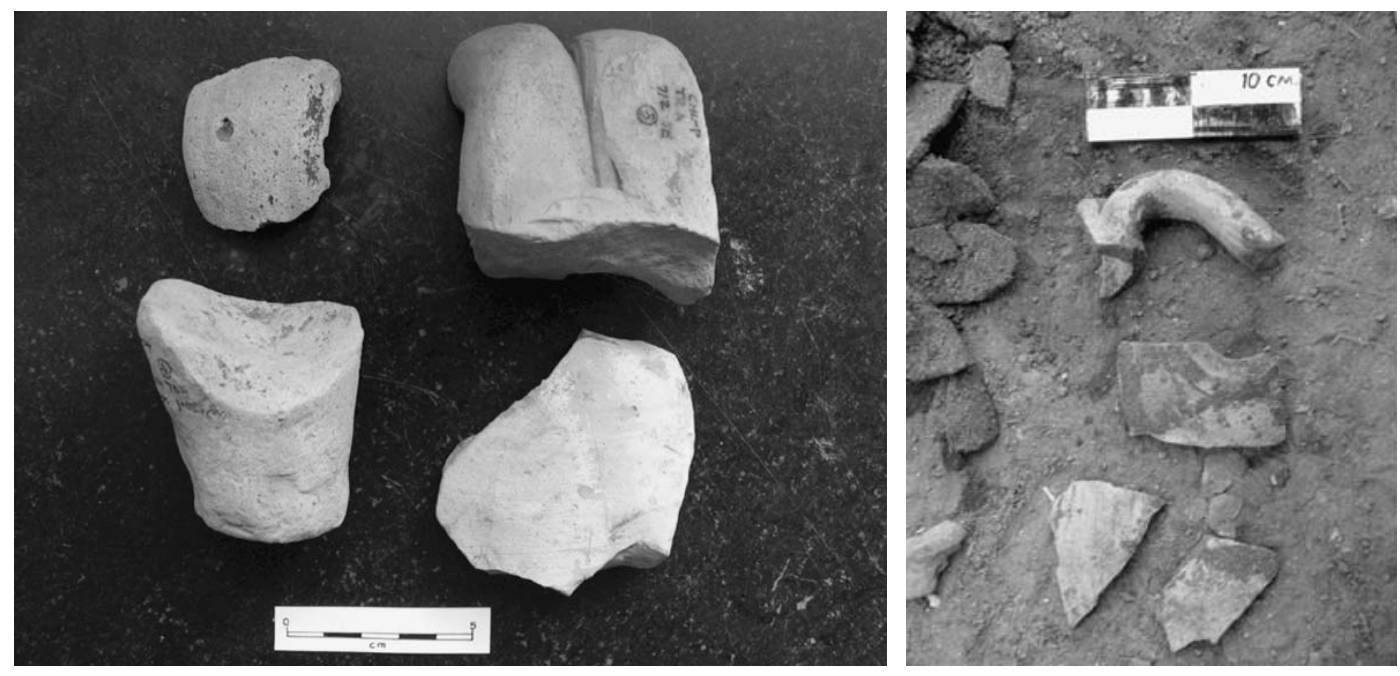

Fig. 10 - Fragmentos de ânforas romanas encontrados em Chaul (foto: Gogte 2003; Aldrovandi 2005).

partes de Mahārāṣtra, e os Sātavāhana, que dominavam Mahārāșțra e Andhra Pradesh, provavelmente trouxeram instabilidade política à região da costa do Gujarate. Assim, é possível que, nesse período, os navios ocidentais tenham evitado os portos mais ao norte e rumado diretamente para Chaul.

Durante a etapa 2005, foram encontrados novos fragmentos de uma ânfora romana na quadra CHL-V. Eles incluem uma alça e partes do corpo do vaso que estão sendo analisados para verificação de procedência e datação. A presença de fragmentos de ânforas no sítio de Chaul pôde comprovar uma intensa atividade comercial entre Roma e Índia a partir do século I a.C., época de florescimento do império Sātavāhana na região oeste indiana.

\section{As grutas budistas de Chaul $^{30}$}

Os três conjuntos de grutas budistas talhados na rocha são os vestígios arquitetônicos

(30) A proposta inicial de nosso estágio no Deccan College incluiu o levantamento da paisagem sagrada budista primitiva no oeste do Deccan, em particular no sítio de Chaul, bem como a análise do desenvolvimento do Budismo e a interação ocorrida entre fatores econômicos e religiosos na região. Ver Aldrovandi (2006, V. II: 508-592). mais antigos associados ao sítio portuário de Chaul, pertencentes ao período Sātavāhana, e se encontram a cerca de $2 \mathrm{~km}$ de distância, nas encostas das montanhas a leste da cidade alta. A montanha na extremidade leste, conhecida como monte Hinglāj, é o ponto mais elevado da cadeia (165m), na qual estão dois conjuntos de grutas. À leste da montanha Hinglāj encontra-se o estreito de Pīr, que separada esta de outra cadeia de montanhas, chamada Sāgargạ̣. A estrada que atravessa a região foi, possivelmente, a principal rota comercial da antiga Chaul para o interior de Mahārāșțra (Fig. 11). Durante a exploração da região para levantamento das grutas budistas, foi encontrado um terceiro conjunto inédito, na face sudoeste da montanha mais próxima ao estreito de Pīr. Tais conjuntos serão descritos a seguir.

\section{III.1. O conjunto monástico de Chaul I}

O primeiro conjunto de grutas budistas Chaul I (N 18³4’05.8", EO 7256’49.2"), está situado na face oeste da montanha Hinglāj, sobre uma plataforma larga e extensa. Entre as seis escavações existentes, pelo menos quatro são do período mais remoto da ocupação budista. $\mathrm{O}$ acesso ao local se dá por meio de uma antiga rota comercial, atualmente asfaltada, que leva até o sopé do morro a cerca de $2 \mathrm{~km}$ de distância do sítio arqueológico da Chaul 


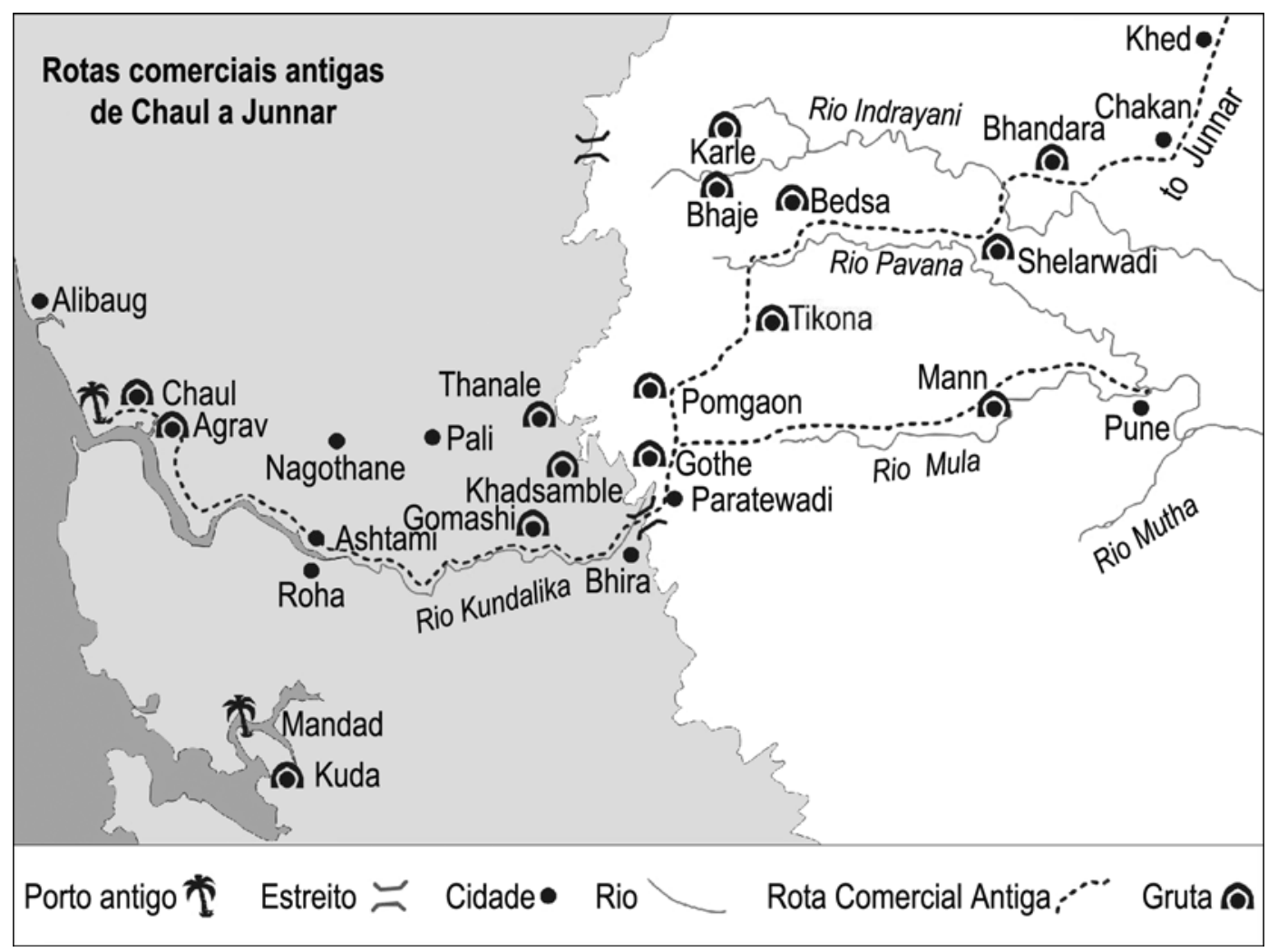

Fig. 11 - Mapa das rotas comerciais associadas às grutas budistas da região de Chaul a Junnar (Marathe 2000).

Alta. O conjunto ${ }^{31}$ está associado às duas conhecidas rotas comerciais que ligavam o porto de Chaul ao planalto do Deccan.

As grutas foram numeradas a partir da extremidade sul. Ao chegar no topo da escadaria observa-se, à direita, a Gruta 1, talhada na rocha e ocupada, no presente, por um templo hindu..$^{32}$ As características arquitetônicas internas da gruta levam a crer que se tratou de uma escavação do

(31) O local foi ocupado, num período mais tardio, pelo templo da deusa Hinglāj, divindade que dá o nome ao monte e que é adorada até os dias atuais. Outras construções modernas foram somadas ao conjunto monástico original. Durante a exploração do conjunto, a área encontrava-se em reforma para festividades religiosas e as grutas haviam recebido uma camada de pintura branca. O conjunto original encontra-se extremamente descaracterizado. Para alcançar as grutas e o templo é preciso subir uma escadaria moderna com 158 degraus. No alto é possível avistar o mar além dos coqueirais de Revdaṇ̣̂ā.

(32) A sala possui cerca de 5,20m de largura por 4,60m de período budista - um vihāra (habitação monástica) simples, com duas celas, que mais tarde foi adaptado. Na parte externa da Gruta 1, à direita, há uma escadaria com trinta degraus, que leva às duas grandes cisternas - poḍhi, talhadas na rocha, ambas do período budista primitivo. ${ }^{33}$

Ao norte, abaixo das cisternas, há um portal que leva à Gruta 2 - o templo atualmente dedicado à deusa Hingglāj - ou Hingulja Bhavāni, que, de

profundidade e sua altura varia entre $1,80 \mathrm{~m}$ e $2 \mathrm{~m}$; a parte da lateral noroeste contém um nicho, atualmente com uma imagem hindu de Āśāpurī Devi. Na parede sul da gruta encontram-se duas celas: a cela leste possui um $1,30 \mathrm{~m}$ por $1 \mathrm{~m}$. de profundidade; a cela oeste possui $1,20 \mathrm{~m}$. de largura por 1,20m de profundidade; na frente da parede oeste da gruta há uma janela, possivelmente original; a fachada da porta com arco ogival e o teto piramidal são acréscimos tardios.

(33) A cisterna mais alta possui 5,5m por 4,30m; a segunda cisterna mede 4,80 por $5,50 \mathrm{~m}$. 
acordo com informações locais, é a protetora dos mercadores. Na frente do templo há um pátio amplo com um pequeno altar com tulasi (ocimum sanctum) e pilares altos com lamparinas. Uma passagem estreita permite a circum-ambulação do templo entre as paredes externas e a rocha da montanha; uma perda no reboco permite observar que as paredes do templo foram originalmente talhadas na rocha. ${ }^{34} \mathrm{~A}$ construção, embora escavada na rocha bruta, não preservou qualquer característica que a associe ao período mais antigo do conjunto monástico, no entanto, existe uma menção à existência de uma antiga cisterna $^{35}$ talhada na rocha, abaixo do nicho que abriga a imagem da deusa, que poderia ser um indício de sua antiguidade. Cerca de $8 \mathrm{~m}$ ao norte deste templo encontram-se as demais grutas do conjunto.

A Gruta 3 possui uma ante-sala e um pequeno santuário, ${ }^{36}$ a construção apresenta características de um vihāra simples, a cela com bancos laterais talhados na rocha - āsanapedhikā, foi adaptada, mais tarde, às necessidades do culto hindu. As escavações 4 e 5 são dois koḍi - um recesso ou nicho talhado na rocha, ambos são elementos arquitetônicos do período de ocupação budista. $^{37}$

(34) O santuário do templo mede 2,5m de largura por 2,30m de profundidade e $2 \mathrm{~m}$ de altura; a ante-sala mede $5,10 \mathrm{~m}$ de comprimento por 3,5m de largura e $2 \mathrm{~m}$ de altura; um teto piramidal recobre essa área; a varanda possui dois pilares e seis pilastras laterais; um teto de telhas frontal foi adaptado sobre dois pilares octogonais.

(35) A cisterna não foi encontrada durante a exploração e possivelmente foi recoberta durante a adaptação tardia. Da Cunha (1876:120) a descreveu com forma quadrada, com 1,50m. de largura e $0,45 \mathrm{~m}$. de profundidade; o autor menciona uma inscrição sobre a cisterna que, já na época de sua visita, estava desgastada. Infelizmente as alterações recorrentes ocorridas nessa gruta não preservaram suas características originais.

(36) A sala mede respectivamente 4,10m de largura por 2,30m de profundidade e 1,60 de altura; uma abertura na parede traseira com $0,50 \mathrm{~m}$ de largura e $1,15 \mathrm{~m}$ de altura leva ao santuário ou à pequena cela ao fundo com $2,35 \mathrm{~m}$ de largura, $1,87 \mathrm{~m}$ de profundidade e $1,60 \mathrm{~m}$ de altura; na parede do fundo há um nicho com $0,50 \mathrm{~m}$. de largura e $0,90 \mathrm{~m}$ de altura no qual se encontra uma imagem da deusa Așţbhujā Devi ou Caturśinghi.

(37) O primeiro mede $1 \mathrm{~m}$ de largura e de altura e aproximadamente $2 \mathrm{~m}$ de profundidade; o segundo, $1 \mathrm{~m}$ de largura, $3,5 \mathrm{~m}$ de profundidade e $1,20 \mathrm{~m}$ de altura. Da Cunha (1876:121) mencionou a existência de duas imagens bramânicas antigas ao fundo deste segundo nicho, no entanto, apenas uma foi encontrada.
Na lateral esquerda encontra-se a Gruta 6, um vihāra bastante descaracterizado. Originalmente a gruta parece ter sido dividida em quatro recintos (celas) menores cujas paredes frontais desmoronaram. ${ }^{38}$ Na parede noroeste ao lado da cela menor está o único elemento iconográfico budista do conjunto: um estupa - dāghobā caitya, talhado em baixo-relevo na rocha ${ }^{39}$ e datado dos séculos I-II d.C (Fig. 12). Na frente dessa gruta existiu uma varanda ${ }^{40}$ que se estendia até a Gruta 3 , como pode ser observado pelos encaixes para pilares de madeira que se preservaram na frente do conjunto. É possível que algumas das grutas tenham sido escavadas num período anterior à Era Cristã. Acima da parede noroeste há uma outra escadaria à direita que leva às cisternas mencionadas anteriormente e à esquerda leva ao topo da montanha até o templo dedicado ao deus Dattātraya.

O conjunto monástico Chaul I é o maior encontrado nessa área próxima ao sítio arqueológico de Chaul, mas suas dimensões modestas indicam que ele teria abrigado apenas um número reduzido de monges.

\section{III.2. As grutas do conjunto Chaul II}

Na face sudeste da montanha Hinglāj encontrase o segundo conjunto de grutas budistas - Chaul II (N 18³4'06.2"; EO 7256'53.1"), composto por apenas duas grutas voltadas para sudeste. Do alto das grutas é possível avistar ao sul o coqueiral de Chaul, o rio Kuṇụalīkā, o forte Korlai e os montes

(38) A cela à direita, na parede sul é quadrada e possui $2 \mathrm{~m}$ de largura e $1,20 \mathrm{~m}$ de altura. O recinto central, possivelmente uma sala, mede $6,20 \mathrm{~m}$ de largura por $2,60 \mathrm{~m}$ de profundidade e 1,60m de altura.; na parede posterior há um banco de pedra com $1,90 \mathrm{~m}$ de largura e $0,70 \mathrm{~m}$ de profundidade, ao qual foi adaptado um armário de madeira. Na lateral oeste há uma cela com $2 \mathrm{~m}$ de largura por $1,80 \mathrm{~m}$ de profundidade e $1,90 \mathrm{~m}$. de altura. A cela junto à parede noroeste mede 1,80 de profundidade e $1,70 \mathrm{~m}$ de largura; possui uma área de rocha bruta que recebeu pintura laranja e, atualmente, é objeto de devoção do culto hinduísta. As celas laterais possuem três fornos modernos de tijolos.

(39) O estupa possui cilindro e faixa com motivo de vedika ao redor; domo hemisférico e um harmikā com cinco plataformas invertidas; acima, um yaștī e um único chattra representados, que alcançam o teto; o domo mede $0,60 \mathrm{~m}$. de largura por $1 \mathrm{~m}$. de altura; o harmikā, o yașțī e o chattra somam $0,45 \mathrm{~m}$ de altura.

(40) Mede 2,20m de largura. 


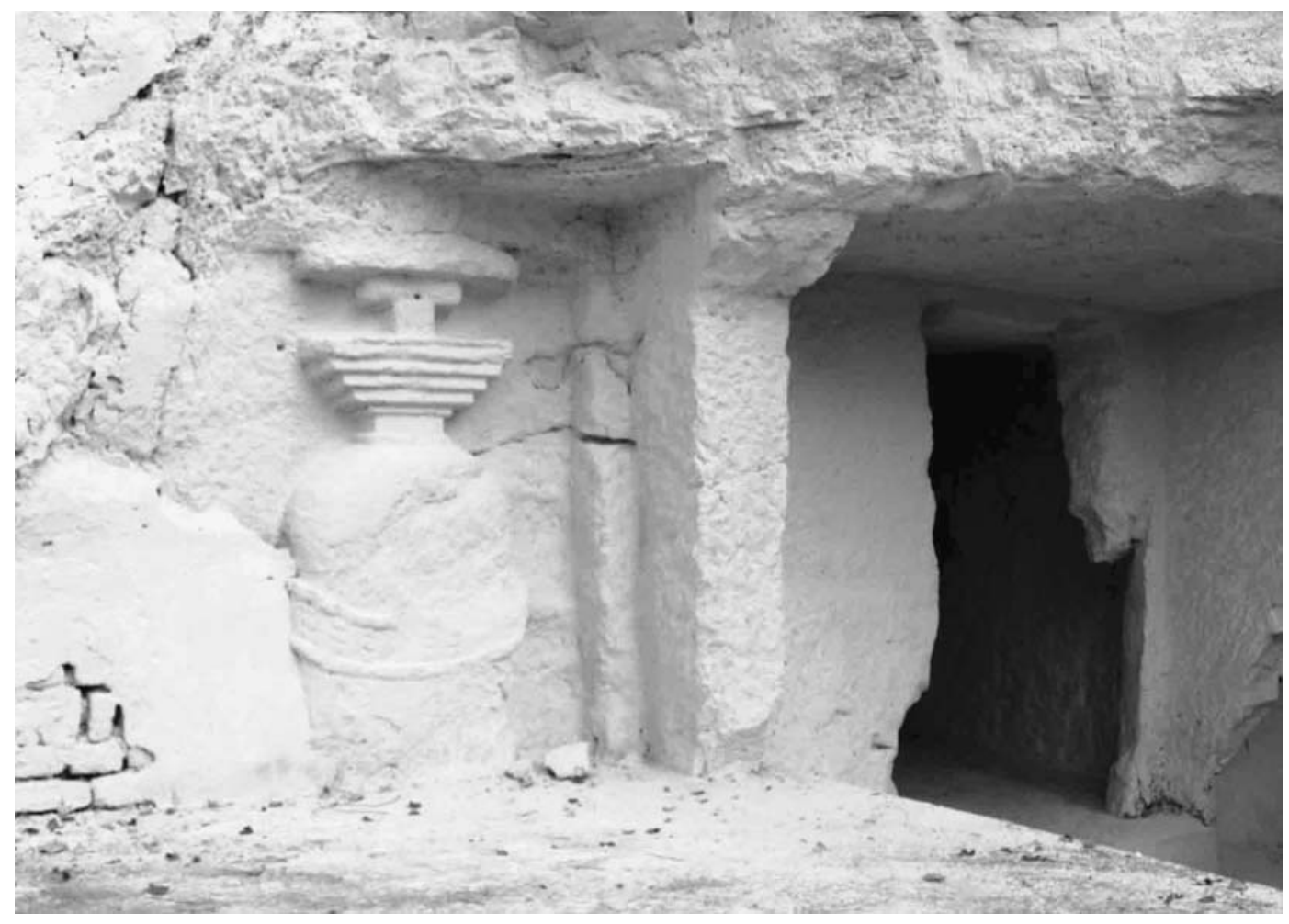

Fig. 12 - Estupa em relevo na parede noroeste da gruta 6 de Chaul I (foto: Aldrovandi 2005).

Jañjīrā; a sudeste observa-se um outro rio que passa ao longo dos montes Rohā. $\mathrm{O}$ acesso a essas grutas é bem mais difícil e exige uma caminhada de cerca de trinta minutos pela encosta desmoronada da montanha. A aproximadamente $30 \mathrm{~m}$ da base da montanha há um vihāra simples e pequeno, ${ }^{41} \mathrm{a}$ parede frontal sofreu desabamento, mas há vestígios de uma varanda estreita; e marcas de cinzel nas paredes. Junto à lateral direita da cela há um $\bar{a}$ sanape ${ }^{\prime} h i k \bar{a}$ (banco talhado na rocha). ${ }^{42}$ Acima do banco, e a cerca de $1 \mathrm{~m}$ à direita (leste) da primeira gruta, encontra-se o segundo vihära, atualmente, de difícil acesso devido ao desmoronamento da rocha na área lateral direita que permitia alcançar a gruta. ${ }^{43}$ Os vihāra não possuem qualquer ornamentação ou

(41) A única cela mede 2,30m de largura por 1,30. de profundidade e $2,40 \mathrm{~m}$ de altura.

(42) Com cerca de $1,50 \mathrm{~m}$ de largura.

(43) A cela simples mede $3,5 \mathrm{~m}$ de largura por $1,80 \mathrm{~m}$ de profundidade e $2 \mathrm{~m}$ de altura; a porta de entrada da cela possui $0,95 \mathrm{~m}$ de largura por $1,65 \mathrm{~m}$ de altura; na inscrição, ambos estão mal conservados e tomados pela vegetação rasteira que se espalha pela montanha. Sua simplicidade remete ao período mais antigo do Budismo primitivo, em que as grutas passaram a ser escavadas para abrigar monges durante os retiros anuais na época das chuvas.

\section{III.3. A gruta do conjunto Chaul III}

Na face sudoeste da montanha mais próxima ao estreito de Pìr se encontra uma gruta budista com estupa - Chaul III (N 18³3’53.8"; EO 7257’10.3"), encontrada durante exploração da área e da qual não havia qualquer registro anterior. $\mathrm{O}$ acesso à frente da cela uma varanda com aproximadamente $3,5 \mathrm{~m}$ por $1,5 \mathrm{~m}$ de largura apresenta perfurações no solo, provavelmente para encaixar as vigas de um telhado ou estrado de madeira, hoje, encobertas pela vegetação. 


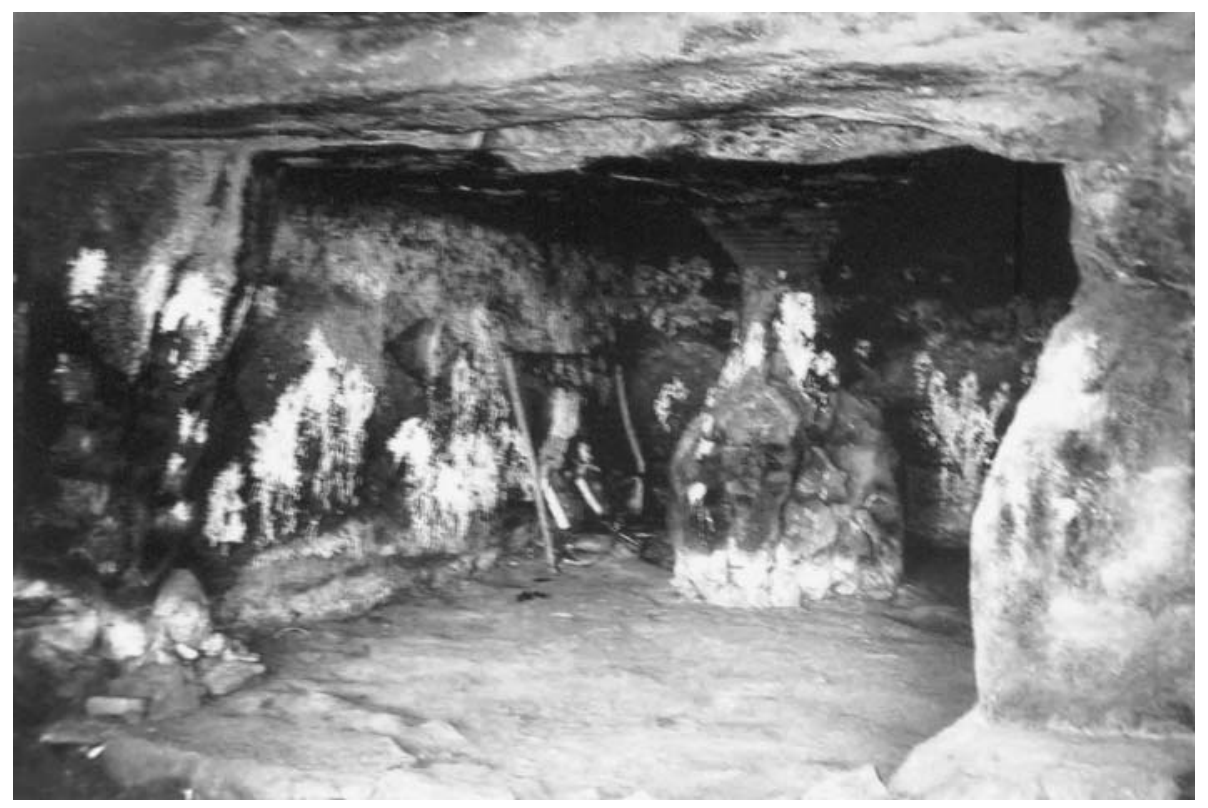

Fig. 13 - O caityagrha com estupa tridimencional do conjunto Chaul III (foto: Gogte 2005).

gruta se dá pela encosta da montanha, numa caminhada de cerca de duas horas. Da entrada da gruta se avistam o rio Kuṇụalīkā e os montes Jañjīirā na margem oposta, ela está voltada para o sul e na fachada externa observa-se uma porta e duas janelas laterais cujos tetos desabaram. ${ }^{44} \mathrm{~A}$ ante-sala ampla possuiu bancadas - āsanape dhik $\bar{a}$, que acompanhavam todo perímetro das paredes internas laterais e posterior. ${ }^{45}$ Ao fundo encontra-se o caityagrha, que abriga o estupa tridimensional (Fig. 13) ${ }^{46}$ A gruta provavelmente pertence aos séculos II ou I a.C. e pode ter sido a mais antiga de Chaul.

(44) A porta mede cerca de 0,90m. de largura; a janela quadrada à direita possui 1,60m. de largura; a esquerda, 2,80m.; ambas com cerca de $1 \mathrm{~m}$. de altura e as laterais desmoronadas.

(45) A ante-sala mede cerca de $8,30 \mathrm{~m}$. de largura por 7,20m de profundidade e $2,20 \mathrm{~m}$ de altura.

(46) Na parede posterior, a abertura que leva à sala quadrada que abriga o estupa possui 4,20m de largura e profundidade; sua altura é de $1,90 \mathrm{~m} O$ estupa tridimencional foi talhado na rocha, no centro da sala e a $0,60 \mathrm{~m}$ de distância da parede posterior; embora bastante danificado, o estupa possui cilindro e domo semicircular com aproximadamente 1,30m de diâmetro; não há vestígios da provável decoração ou encaixes no cilindro; um harmikà quadrado e longo se eleva até a plataforma de sete degraus invertidos junto ao teto; o estupa possui a

\section{Considerações finais}

Embora se trate de resultados parciais, as evidências coletadas durante as etapas de campo 2003 a 2005 confirmaram uma ocupação contínua do sítio de Chaul por mais de 2000 anos: desde o período Maurya - séculos III-II a.C., até o final do século XVII d.C., pois, à exceção do nível estratigráfico (6) estéril, todos os demais apresentaram uma quantidade expressiva e ininterrupta de vestígios arqueológicos. mesma altura da sala. As características apresentadas pelo estupa, embora bastante danificadas, podem ser observadas num dos estupas memoriais da gruta 20 de Bhàjà, cujos exemplares mais tardios - com chattra, foram datados do século II d.C. Ao lado do estupa encontram-se dois relevos apoiados na parede esquerda com divindades hindus - provavelmente trazidos de algum antigo templo nas redondezas e que são objeto de culto dos habitantes locais. As marcas brancas e vermelhas nas paredes internas, as cruzes suásticas nas paredes externas e internas, os tijolos espalhados pelo chão e utilizados como fogareiro, os troncos e gravetos queimados confirmam um uso recente, possivelmente de um ou mais ascetas hindus que costumam vagar pela região. 
A dinâmica das trocas comerciais com o Império Romano, Pérsia, China e costa leste da África, mencionadas nas fontes textuais, foram comprovadas pelas evidências arqueológicas coletadas durante as etapas de campo. Chaul possui grande potencial para compreensão das relações comerciais existentes entre $\mathrm{o}$ antigo porto e os sítios do planalto, como Paithan, Nevasa, Junnar e Nasik em Mahārāștra, bem como com os sítios costeiros do Gujarate e Malabār (Kerala).

A análise do material arqueológico presente nos níveis estratigráficos associados aos períodos Sātavāhana e Medieval Inicial, dos quais não existe muita informação histórica, certamente trará novos e importantes resultados. A presença de grutas budistas associadas ao sítio de Chaul - datadas dos séculos I a.C. ao II d.C. insere, por sua vez, esta paisagem sagrada na dinâmica das trocas comerciais da região do Konkan e Deccan, durante o período Sātavāhana. A existência de grutas budistas ao longo das antigas rotas comerciais e a relação entre monges budistas e mercadores é reconhecida há mais de um século. Em troca de abrigo para as caravanas, os comerciantes faziam donativos para construção das grutas, comprovados pelas inscrições recorrentes encontradas nos conjuntos monásticos. Nesse sentido, as grutas budistas podem ser utilizadas como marcos para traçar as antigas rotas comerciais que ligavam Chaul, no litoral do Konkan, ao planalto do Deccan. ${ }^{47}$

Uma análise preliminar a respeito do declínio do sítio portuário de Chaul indica que este esteve, provavelmente, associado a dois fatores principais: um geomorfológico, devido à mudança gradual do curso do leito do rio Kuṇụalīkā, atualmente com cerca de $1 \mathrm{~km}$ de depósito de aluvião, o assoreamento progressivo inviabilizou, com o passar do tempo, a chegada de navios de grande porte até o porto de Chaul; e, um segundo, político, ocorrido a partir do período em que os britânicos firmaram seu monopólio do comércio marítimo e escolheram Bombaim (Mumbai) como principal porto para suas transações internacionais, o desenvolvimento intenso dessa região portuária contribuiu diretamente para o declínio gradual dos demais portos comerciais da costa oeste, entre eles, Chaul.

A pesquisa e a análise aprofundada do material arqueológico ainda se encontra em desenvolvimento. Novas etapas de campo estão previstas para 2006, o que certamente trará resultados novos e importantes para a compreensão das principais questões políticas, econômicas e religiosas que permearam a história do sítio arqueológico de Chaul na Índia antiga.

\section{Agradecimentos}

A todos aqueles que estão direta ou indiretamente envolvidos na pesquisa. Ao Diretor e demais membros do NIOT, Chennai, pelo apoio e financiamento das escavações arqueológicas. À Fapesp pelo financiamento do estágio no Deccan College. 
GOGTE, V.D.; ALDROVANDI, C.E.V. Simylla of the Periplus Maris Erythraei: Archaeological Excavation at the Ancient Port of Chaul in the West Coast of Mahārāștra - Índia. Rev. do Museu de Arqueologia e Etnologia, São Paulo, 15-16: 247-269, 2005-2006.

ABSTRACT: The article presents the results from the archaeological research undertaken by the Deccan College Post-Graduate and Research Institute team at the port of Chaul, known in the ancient accounts as one of the major trade centers on the west coast of India. Archaeological evidence recovered during exploration and excavation confirmed its existence since Mauryan e Sātavāhana times. Roman amphorae sherds were also recovered. Three groups of Buddhist caves were explored near the archaeological site belonging to the Sātavāhana period. Continous occupation was attested by habitational levels spanning for more than 2 thousand years, until the seventeenth century, when the ancient port lost its economic pre-eminence to Mumbai.

UNITERMS: Ancient India - Archaeology - Economy - Sātavāhana - Rome Buddhism.

\section{Referências bibliográficas}

ABBOTT, J.E.

1891 Recently discovered Buddhist caves at

Nadsur and Nenavli in the Bhor state,

Bombay Presidency. Indian Antiquary, $X X$ : 120-9.

ALDROVANDI, C.E.V.

2006 As Exéquias do Buda Śākyamuni: Morte, Lamento e Transcendência na Iconografia Indiano-Budista de Gandhāra. Tese de Doutorado. São Paulo, Museu de Arqueologia e Etnologia da Universidade de São Paulo.

BIENKOWSKI, P.

1996 Treasures from an Ancient Land: the Art of Jordan. Gloucestershire: Alan Sutton Publishing.

BURGESS, J.

1883a Reports on the Buddhist Cave Temples and their inscriptions. Archaeological Survey of Western India Publication Series IV, London.

CASSON, L.

1980 Rome's trade with the East: the Sea Voyage to Africa and India. Transactions of the American Philological Association, 110: 2136.

1989 The Periplus Maris Erythraei. Princeton: Princeton University Press.

CODRINGTON, K.B.

1930 Ancient Sites near Ellora, Deccan. Indian Antiquary, LIX: 10-9.

CUNNINGHAM, A.

1871 The Ancient Geography of India. London. DACUNHA, G.

1876 Notes on the History and Antiquities of Chaul and Bassein. Bombay: Thacker, Vining \& Co.
DATTA, A.

2001 Terracotta Ringwells and Early Historic Settlements in West Bengal: a Study. Journal of Bengal Art, vol. 6: 93-100.

DEHEJIA, V.

1972 Early Buddhist Rock Temples: a Chronological Study. London: Thames and Hudson.

DELLAVALLE, $\mathrm{P}$.

1667 Viaggi (1623-1625).

DUBIN, L.S.

1995 The History of Beads. London: Thames and Hudson.

FILLIOZAT, J.

1949 Les échanges de l'Inde et de l'Empire romain, au premièrs siècles de l'ère chrétienne. Revue Historique, 201: 5-6.

GATHE, S.

1990 Palaeogeography of Chaul: a Coastal Town on North Konkan Coast. Bulletin of the Deccan College Post-Graduate and Research Institute, 49:145-48.

GOGTE,V.D.

1996 Chalcolithic Balathal - a Trading Centre as Revealed by the XRD Study of Ancient Pottery. Man and Environment, XXI (1):10310.

2002 Ancient Maritime Trade in the Indian Ocean: evaluation by Scientific Studies of Pottery. Man and Environment, XXVII (1): 57-67.

2003 Discovery of the Ancient Port of Chaul. Man and Environment, XXVIII (1): 68-74.

2004 Discovery of an Ancient Port: Palaepatmai of the Periplus on the West Coast of India”. Journal of Indian Ocean Archaeology, I: 124-32. 
GUPTA, S.P.; DALAL, K.F.; DANDEKAR, A.; NANJI, R.; ARAVAZHI, P.; BOMBLE, S.

2004 On the footsteps of Zoroastrian Parsis in India: Excavation at Sanjan on the West Coast, 2003. Journal of the Indian Ocean Archaeology, 1: 93-106.

HUNTINGFORD, GW.B.

1980 The Periplus of Erythraean Sea. London: The Hakluyt Society.

JOSHI, M.C.

1990 Historical Urbanization in Indo-Pak SubContinent: a Reassesment. N.Delhi: Books \& Books.

JULIEN, S.

1858 Hiuen Thsang: Mémoire analytique, étude sur la géographie grecque et latine de l'Inde. 2vols, Paris.

KARTTUNEN, K.

1989 India in Early Greek Literature. Studia Orientalia, vol. 65. The Finnish Oriental Society (Ed.), Helsinki.

KOSAMBI, D.D.

1955 Dhenukakata. Journal of the Asiatic Society of Bombay, 30: 51-63.

LENNART BERGGREN, J.; JONES, A.

2001 Ptolemy's "Geography", an Annotated Translation of the Theoretical Chapters. Princeton: Princeton University Press.

MAC CRINDLE, J.W.

1901 Ancient India as described in Classical Literature. Westminster.

1905 Periplus of the Erythraean Sea. London.

1960 Ancient India as described by Megasthenes and Arrian. Calcutta.

MAC DOWALL, D.W.

1964 The Early Western Satrapas and the Date of the 'Periplus'. Numismatic Chronicle, s.7, 4: 48-64.

MAJUMDAR, R.C.; PUSALKAR, A.D. (EDS.)

1953 The Age of Imperial Unit. Bombay.

MASUDI.

1989 Murui al-dahab: Les Prairies d'Or. Barbier de Maynard et Pavet de Courteille (trad.), 5 tomes. Paris: Librairie Orientaliste Paul Geuthner (1862-1897).

MARATHE, V.

1999-2000 Unveiling the Ancient Trade Route of Paratewadi. Puratattva, 30: 161-3.

NAGARAJU, $\mathrm{S}$.

1981 Buddhist Architecture of Western India (c. 250 B.C. c. A.D.300). Delhi: Agam Kala Prakashan.

PALMER, J.A.B.

1947 Periplus Maris Erythraeis, the Indian Evidence as to the Date. Classical Quarterly.

PANDE, B.M.

1964 Ringwells in Ancient India. Bulletin of the Deccan College Research Institute, 25: 12-3.
PIRENNE, J.

1961 La date du Périple e la Mer Érythrée. Journal Asiatique, 4: 441-60.

PTOLOMEU, C.

1883 Geographia. Parisiis: Alfredo Firmin Didot. RASCHKE, M.G

1979 The Role of Oriental Commerce in the Economies of the Cities of the Eastern Mediterranean in Roman Period. Archaeological News, 8: 68-77.

SANKALIA, H.D.; DIKSHIT, M.G.

1952 Excavations at Brahmapuri (Kolhapur) 1945-46. Pune: Deccan College.

SANKALIA, H.D.; DEO, S.B.; ANSARI, Z.D.; EHRHARDT, S.

1960 From History to Pre-History at Nevasa (1954-56). Pune: Deccan College.

SASTRI, S.M.

1927 McCrindle's Ancient India as Described by Ptolemy. Calcutta: Chuckervertty, Chatterjee and Co. Ltd.

SCHOFF, W.H. (ED.)

1912 The Periplus of the Erythraean Sea: Travel and Trade in the Indian Ocean by a Merchant of the First Century. New York: Longmans, Green and Co.

SCHOFF, W.H.

1917 The date of the Periplus. Journal of the royal Asiatic Society: 827-43.

SEDOV,A.V.

1998 'Qana' (Yemen) and the Indian Ocean: the Archaeological Evidence. H.P. Ray; J.F. Salles (Eds.) Tradition and Archaeology: Early Maritime Contacts in the Indian Ocean. New Delhi, Manohar: 11-36.

STERN, E.M.

1991 Early Roman Export Glass in India. V. Begley; R.D. De Puma (Eds.) Rome and India: the Ancient Sea Trade. Madison, University of Wisconsin Press: 157-196.

TEIXEIRA, M.C.

1996 Portuguese Colonial Settlements of the $15^{\text {th }}$ $18^{\text {th }}$ centuries. C. Coquery-Vidrovitch; O. Goerg (Eds.) La ville européenne outre mer: un modèle conquérant? (XVe-XXe siècles). Paris, L'Harmattan: 15-26.

WARMINGTON, E.H.

1995 The Commerce Between the Roman Empire and India. New Delhi, Munshiram Manoharlal Pub. Pvt. Ltd. (1928).

WARMINGTON, E.H.

1934 Greek Geography. London.

WHEELER, R.E.M., GOSH, A.; DEVA, K.

1946 Arikamedu: an Indo-Roman Trading Station on the East Coast of India. Ancient India, 2: 17-124.

WILL, E.L.

1992 The Mediterranean Shiping Amphoras from Arikamedu. V. Begley; R. de Puma (Eds.) Rome and India: the Ancient Sea Trade. Delhi: Oxford University Press: 151-6. 